\title{
Advances in thermal energy storage materials and their applications towards zero energy buildings: A critical review
}

\author{
Jesús Lizana a \\ Ricardo Chacartegui ${ }^{b}$ \\ Angela Barrios-Padura a \\ José Manuel Valverde ${ }^{c}$ *

\begin{abstract}
a Departamento de Construcciones Arquitectónicas, Universidad de Sevilla, Avda. Reina Mercedes 2, 41012 Seville, Spain
b Departamento de Ingeniería Energética, Universidad de Sevilla, Camino de los Descubrimientos s/n, 41092 Seville, Spain cFacultad de Física, Universidad de Sevilla, Avda. Reina Mercedes s/n, 41012 Seville, Spain
\end{abstract} \\ * Corresponding author. E-mail address: jmillan@us.es
}

\begin{abstract}
Buildings are responsible for one-third of the world's energy consumption, of which $60 \%$ is due to heating and cooling. To accomplish the low-carbon energy goal in the building sector, thermal energy storage offers a number of benefits by reducing energy consumption and promoting the use of renewable energy sources. This manuscript reviews recent advances in the development of thermal energy storage materials for building applications oriented towards zero energy buildings. Volumetric heat capacity of sensible, latent and thermochemical energy storage materials developed for lowto-moderate temperature applications are reviewed and assessed with a special focus on their technical characteristics and development stage. This encompasses most recent publications, international programmes and projects, and commercially available solutions. Physical, thermodynamic, kinetic and chemical properties are addressed, as well as costs. Advantages, drawbacks and challenges of the diverse alternatives are discussed. The analysis shows that solutions with the highest potential for competitive energy efficiency measures are based on latent and sensible energy storage systems, which present a volumetric thermal energy storage density up to 430 and $250 \mathrm{MJ} / \mathrm{m}^{3}$ respectively. Their applications in free-cooling ventilation systems, solar energy storage solutions for short and long-term storage periods, and demand-side management strategies towards the road to zero energy buildings are highlighted as promising, leading to a reduction of energy consumption of more than $30 \%$. On the other hand, thermochemical energy storage does not yet show clear advantages for building applications, despite the potentially high energy density (up to $1510 \mathrm{MJ} / \mathrm{m}^{3}$ ) and heat availability for long-term storage periods. Currently, there is no available material for thermochemical energy storage that satisfies all the requirements for building operations. Besides, thermochemical solutions require different tanks and heat exchangers that should be carefully addressed for small-scale applications. Additional research efforts are needed to optimise operation conditions, efficiency, costs and system designs.
\end{abstract}

Keywords: Thermal energy storage, Energy efficiency, Sensible heat storage, Latent heat storage, Thermochemical storage, Zero energy buildings. 


\section{Nomenclature}

\begin{tabular}{ll}
$c_{p}$ & specific heat $\left(\mathrm{KJ} / \mathrm{kg}^{\circ} \mathrm{C}\right)$ \\
CSMP & Composite salt in porous matrix \\
DH & District heating \\
DHW & Domestic hot water \\
DSM & Demand-side management \\
GHG & greenhouse gas \\
$h_{f}$ & latent heat of fusion per unit mass $(\mathrm{kJ} / \mathrm{kg})$ \\
HVAC\&R & Heating, ventilation, air conditioning and refrigeration \\
$m$ & mass of heat storage medium $(\mathrm{kg})$ \\
PCM & phase change material \\
PV & photovoltaic \\
$Q$ & quantity of heat stored $(\mathrm{MJ})$ \\
SHSM & sensible heat storage material \\
T & temperature $\left({ }^{\circ} \mathrm{C}\right)$ \\
TABS & thermally Activated Building system \\
TES & thermal energy storage \\
TMA & thermal mass activation \\
TSM & thermochemical energy storage material \\
UTES & underground thermal energy storage \\
ZEB & zero energy building \\
& \\
\hline Greek letters & \\
$\alpha$ & thermal diffusivity (mm² $/ \mathrm{s})$ \\
$\lambda$ & thermal conductivity $\left(\mathrm{W} / \mathrm{m}^{\circ} \mathrm{C}\right)$ \\
$\rho$ & density $\left(\mathrm{kg} / \mathrm{m}^{3}\right)$ \\
$\mathrm{S}$ ) & \\
\hline & \\
& \\
&
\end{tabular}




\section{Introduction}

The building sector is the largest energy-consuming sector, accounting for over one-third of the final energy consumption in the world [1]. In the European Union, it is responsible for $40 \%$ of the total energy consumption [2] of which heating, cooling and hot water are responsible for approximately $70 \%$ [1]. Currently, around $75 \%$ of the primary energy supply for heating and cooling is based on fossil fuels [3]. In the pathway towards an energy sustainable, efficient, environmentally friendly and low-carbon building sector, thermal energy storage (TES) offers a great range of opportunities and benefits to reduce energy consumption and GHG emissions $[1,4,5]$.

TES solutions can be based on sensible, latent or thermochemical energy storage [6] and may be implemented in buildings through passive and active applications [7,8]. Passive applications allow reducing energy demand in buildings by means of a higher thermal inertia, decreasing indoor peak-temperature, and improving thermal comfort [4,5]. On the other hand, active applications allow [1,5]:

i) Reducing the peak load thanks to the supply of stored energy, which reduces the required power capacity of heating/cooling equipment;

ii) Improving the efficiency of systems by adjusting the operation range (avoiding operations at partial loads and mitigating intermittent input by frequent startstop);

iii) Increasing renewable energy contribution, mainly solar and aero-thermal energy, by overcoming the time mismatch between demand and supply.

Despite the fact that a huge research effort has been carried out on energy storage in recent years $[9,10]$, competitive TES materials and technologies are being developed slower than expected [11]. An efficient integration of available TES technologies into the architecture of buildings remain to be technically and commercially developed [8,12]. Nonetheless, applications are gradually becoming more feasible due to the significant increases of energy prices [13] and regulatory pressure [2].

This paper provides a critical review of current state-of-the-art TES materials and applications towards Zero Energy Buildings (ZEBs). Classification and characterisation properties of available sensible, latent and thermochemical TES materials and their applications are reviewed according to the most recent publications and international programmes and projects. This encompasses TES materials, technically and commercially developed for low-temperature applications as required for direct application in buildings: up to $21^{\circ} \mathrm{C}$ for cooling applications, between $22^{\circ} \mathrm{C}$ and $28^{\circ} \mathrm{C}$ for comfort applications, and over $29^{\circ} \mathrm{C}$ for hot water and heating applications. A novel comparison of TES materials is carried out taking into account volumetric heat capacity instead of mass heat capacity Assessment of the latter is more appropriate for building applications due to space limitations. Physical, thermodynamic, kinetic and chemical properties of materials are compared, as well as costs, and current research stages are discussed with the aim of identifying advantages, drawbacks and challenges for their application and deployment. The results of the review allow the identification of the most promising TES materials and technologies for building implementation towards ZEBs at different scales (per dwelling, medium-scale buildings and district networks) with current development levels. This review is also expected to contribute as a guide for the decision-making process in the development of efficient TES solutions for buildings. 


\section{Overview. Classification of Thermal Energy Storage materials and their applications}

TES solutions for building applications can be based on sensible, latent or thermochemical energy storage materials.

- Sensible heat storage is the most widely used technique for building applications. It is simply based on increasing or decreasing the temperature of a high heat capacity storage medium, thus storing and releasing heat [14]. The average TES capacity of most materials employed is approximately $100 \mathrm{MJ} / \mathrm{m}^{3}[6]$, with water being the most practical available material having a storage capacity of $250 \mathrm{MJ} / \mathrm{m}^{3}$ for a temperature gradient of $60^{\circ} \mathrm{C}$ [15].

- Latent heat storage consists of storing or releasing heat in the storage medium when it undergoes a phase change (from one physical state to another) $[14,16]$. Compared to sensible heat storage, phase change materials (PCM) can store a larger amount of heat in a much shorter temperature range around the phase change temperature. According to Tatsidjodoung et al. [6], the typical latent heat storage capacity of most materials usable for this end is in the range $300-500 \mathrm{MJ} / \mathrm{m}^{3}$.

- Thermochemical heat storage relies on the use of a source of heat to induce a reversible chemical reaction and/or sorption process $[17,18]$. The potential benefits of these storage systems is their rather high energy density (approximately $1000 \mathrm{MJ} / \mathrm{m}^{3}$ [6]), negligible heat loss, and long-term heat availability [19].

Sensible, latent and thermochemical energy storage materials can be implemented in buildings by means of different applications. Figure 1 illustrates the relationship between main TES applications and storage methods according to the classification described in $[7,8,16,20,21]$.

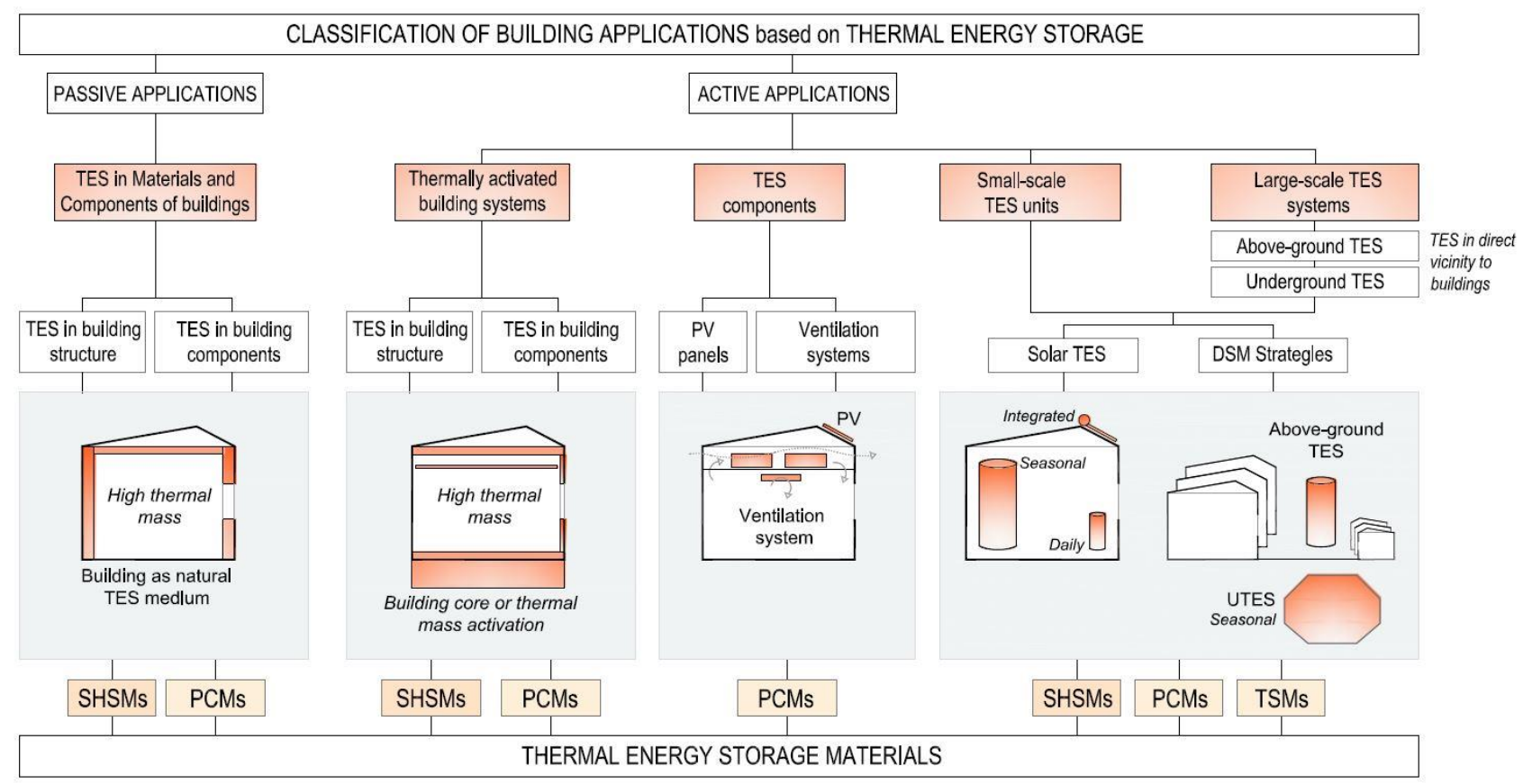

Figure 1. Building applications based on thermal energy storage.

Depending on their characteristics, these applications can be divided into passive and active, ranging from high thermal inertia conventional solutions in buildings to advanced TES units:

- TES in materials and components of buildings consist of high thermal inertia elements, which improve the thermal performance of buildings by the attenuation of thermal oscillations in the indoor space. Only sensible heat storage and latent heat storage are used in passive building applications [7].

- Thermally Activated Building systems (TABS) [21] or Thermal mass activation (TMA) [8] refers to using the building structure as a TES system through active applications. The operation mode consists of connecting a construction element of high heat capacity with a thermal energy source. Only sensible heat storage and latent heat storage are used in these applications. 
- TES components are based on encapsulated PCMs and they are used for improving the environmental performance of systems, mostly taking advantage of night ventilation, in order to freeze the PCM for cooling purposes during daytime, absorbing heat gains and mitigating overheating [22]. Thus, it works as a free cooling system by reducing temperature peaks during daytime. The applications of TES components can be classified into two groups: PCM applied to ventilation systems for free cooling ventilation, and PCM applied to PV panels for increasing the electrical yield thanks to a reduction of temperature rise of their surface compared to a system without PCMs [2325].

- Small-scale TES units refers to compact storage tanks for heating and cooling applications, which can be based on the form of sensible, latent or thermochemical storage. This allows increasing the renewable energy use (through seasonal or daily storage) and/or improving the energy performance of heating, ventilation, air conditioning and refrigeration (HVAC\&R) systems $[1,5]$.

- Large-scale TES systems refer to above-ground large-scale water tanks and underground thermal energy storage (UTES) systems. Their main applications consist of solar storage in district heating (DH) networks or large-scale buildings.

The next sections are focused on the characterisation of the best available TES materials for building applications based on sensible, latent and thermochemical energy storage according to commercial data, most recent publications, and international programmes and projects. It must be remarked though that for each storage method, the reported studies use diverse measurement methodologies and test protocols, which are often not defined in detail. Therefore, the solutions proposed are difficult to compare directly as the differences in measurement methods (e.g., energy density taking into account stored energy or released energy, measurement conditions of thermal properties, etc.) and operation conditions (e.g., operation temperatures, flowrate, pressure, operation time, initial-final dehydration levels (\%), etc.) have a large influence on the properties measured [6]. To circumvent this issue, it would be necessary to employ measurementstandards for energy storage materials and systems.

\section{Sensible heat storage materials}

\subsection{Classification and characterisation parameters.}

Sensible heat storage materials (SHSMs) can be either liquid or solid storage materials [26]. The thermodynamic, physical, chemical and economic parameters of SHSMs are listed in Table 1 [26,27]. Thermal reliability (no change in thermal properties) and chemical stability (no decomposition or change in chemical composition) after a large number of thermal cycles, and thermal stability (no degradation or weight loss) at high temperatures should be guaranteed to assure a long lifetime. 
Table 1. Characterisation parameters of SHSMs.

\begin{tabular}{llll}
\hline Thermodynamic & Physical & Chemical & Economic \\
\hline Specific heat $\left(c_{p}\right)\left(\mathrm{kJ} / \mathrm{kg}^{\circ} \mathrm{C}\right)$ & Density $(\rho)\left(\mathrm{Kg} / \mathrm{m}^{3}\right)$ & No chemical decomposition & Available in large quantities \\
Thermal conductivity $(\lambda)\left(\mathrm{W} / \mathrm{m}^{\circ} \mathrm{C}\right)$ & Volume change $(\%)$ & Non-corrosive & Inexpensive \\
Thermal diffusivity $(\mathrm{a})\left(\mathrm{mm}^{2} / \mathrm{s}\right)$ & & Non-poisonous & \\
Thermal effusivity $\left(\mathrm{W} \sqrt{s} / \mathrm{m}^{2} \mathrm{o} C\right)$ & & Non-flammable & \\
Thermal expansion coefficient $(\%)$ & & Non-explosive & \\
\hline
\end{tabular}

The amount of energy stored as sensible heat $(Q)$ in a given mass of material $(m)$ is given by Eq. 1 [28,29]. Thus, high specific heat and high density should be pursued to achieve a high volumetric storage capacity $\left(\mathrm{MJ} / \mathrm{m}^{3}\right)$. As a reference value, the sensible heat storage capacity of water for a temperature difference $(\Delta T)$ of $60^{\circ} \mathrm{C}$ is $250 \mathrm{MJ} / \mathrm{m}^{3}$.

$$
Q=\int_{T i}^{T f} m c_{p} d T \quad(M J)
$$

Charging/discharging periods and power depend on thermal conductivity, exchange flow rate and thermal diffusivity (a), which provide stratification ability. Thermal diffusivity measures the rate at which the temperature changes within a substance, and is defined in terms of thermal conductivity, density, and heat capacity according to Eq. 2.

$$
\alpha=\frac{\lambda}{\rho \cdot c_{p}}\left(m m^{2} / s\right)
$$

High thermal stratification allows releasing heat easier, as it allows transferring a low temperature thermal energy source to the cooler regions in a charged thermal storage medium, and higher quality energy (exergy) is readily available from the warmer regions of a discharged thermal storage medium [30].

For passive applications, Ståhl [27] analysed the influence of thermal mass on the heating and cooling demands in buildings, and found that the main influencing parameter on building thermal inertia is the thermal effusivity (Eq. 3), which characterises the rate at which a material can absorb heat. The higher the thermal effusivity the greater the amount of heat stored and thus the higher the building energy consumption reduction.

$$
\text { Thermal effusivity }=\sqrt{\lambda \cdot \rho \cdot c_{p}}\left(\mathrm{w} \sqrt{s} / m^{2} K\right) \quad \text { Eq. } 3
$$

Small volume change, availability, low cost and non-toxicity are also important variables to take into consideration.

The main drawbacks of SHSMs are related to their low energy density (owing to space limitation for building applications) and self-discharge of the system, which can be substantial due to heat losses (particularly for long-period storage) [6].

\subsection{Evaluation of available sensible heat storage materials.}

Table 2 summarises the properties of main construction materials for sensible heat storage according to $[6,15,31,32]$. Material cost data was gathered from a number of commercial databases [33-35]. Average volumetric specific heat capacity data have been calculated according to average parameters of density and specific heat. 
Table 2. Available SHSMs for building applications.

\begin{tabular}{|c|c|c|c|c|c|c|c|}
\hline \multirow[b]{2}{*}{ Reference } & \multirow[b]{2}{*}{ Material } & \multirow[b]{2}{*}{$\begin{array}{c}\text { Average material } \\
\text { cost } \\
{[33-35]}\end{array}$} & \multirow[b]{2}{*}{ Type } & \multicolumn{4}{|c|}{ Properties } \\
\hline & & & & $\begin{array}{l}\text { Density } \\
\left(\mathrm{kg} / \mathrm{m}^{3}\right)\end{array}$ & $\begin{array}{c}\text { Thermal } \\
\text { conductivity } \\
\left(\mathrm{W} / \mathrm{m}^{\circ} \mathrm{C}\right) \\
\end{array}$ & $\begin{array}{c}\text { Specific heat } \\
\text { capacity } \\
(\mathrm{kJ} / \mathrm{kgK})\end{array}$ & $\begin{array}{l}\text { Average volumetric } \\
\text { specific heat } \\
\text { capacity }\left(\mathrm{kJ} / \mathrm{m}^{3} \mathrm{~K}\right)\end{array}$ \\
\hline Asan and Sancaktar [32] & Asphalt sheet & $56 € / m^{3}$ & Solid & 2300 & 1.2 & 1.7 & 3910 \\
\hline Tatsidjodoung et al. [6] & Oil & $6560 € / \mathrm{m}^{3}$ & Liquid & 888 & 0.14 & 1.88 & 1669 \\
\hline Tudela [31] & Ceramic brick & $36-64 € / m^{3}$ & Solid & 1800 & 0.73 & 0.92 & 1656 \\
\hline & Wood & $404 € / m^{3}$ & Solid & 450 & 0.12 & 1.6 & 720 \\
\hline & Plywood boards & $1114 € / \mathrm{m}^{3}$ & Solid & 500 & 0.13 & 1.6 & 800 \\
\hline & Gypsum (plasterboard) & $385 € / \mathrm{m}^{3}$ & Solid & 900 & 0.25 & 1 & 900 \\
\hline & Gypsum (coating) & $78 € / \mathrm{m}^{3}$ & Solid & 1000 & 0.4 & 1 & 1000 \\
\hline & Oriented strand board & $328 € / \mathrm{m}^{3}$ & Solid & 600 & 0.14 & 1.7 & 1020 \\
\hline & Wood & $404 € / m^{3}$ & Solid & 700 & 0.18 & 1.6 & 1120 \\
\hline & Oriented strand board & $328 € / \mathrm{m}^{3}$ & Solid & 900 & 0.18 & 1.7 & 1530 \\
\hline & Ceramic tile & $1600-3500 € / \mathrm{m}^{3}$ & Solid & 2000 & 1 & 0.8 & 1600 \\
\hline & Lime mortar & $123 € / \mathrm{m}^{3}$ & Solid & 1600 & 0.8 & 1 & 1600 \\
\hline & Plywood boards & $1114 € / \mathrm{m}^{3}$ & Solid & 1000 & 0.24 & 1.6 & 1600 \\
\hline & Cement bonded particleboard & $1309 € / \mathrm{m}^{3}$ & Solid & 1200 & 0.23 & 1.5 & 1800 \\
\hline ISO 10456:2007 [15] & Cement mortar & $115 € / \mathrm{m}^{3}$ & Solid & 1800 & 1 & 1 & 1800 \\
\hline & Concrete & $76 € / \mathrm{m}^{3}$ & Solid & 2000 & 1.35 & 1 & 2000 \\
\hline & Sand and gravel & $6-8 € / \mathrm{m}^{3}$ & Solid & $1700-2200$ & 2 & $0.910-1.180$ & 2072 \\
\hline & Limestone & $70-819 € / \mathrm{m}^{3}$ & Solid & $1600-2600$ & $0.85-2.3$ & 1 & 2100 \\
\hline & Rock & $64-742 € / \mathrm{m}^{3}$ & Solid & $2800-1500$ & $3.5-0.85$ & 1 & 2150 \\
\hline & Concrete (high density) & $100 € / \mathrm{m}^{3}$ & Solid & 2400 & 2 & 1 & 2400 \\
\hline & Reinforced concrete $(2 \%)$ & $121 € / \mathrm{m}^{3}$ & Solid & 2400 & 2.5 & 1 & 2400 \\
\hline & Clay or silt & - & Solid & $1200-1800$ & 1,5 & $1.670-2.500$ & 3252 \\
\hline & Water $\left(80^{\circ} \mathrm{C}\right)$ & $1.6 € / \mathrm{m}^{3}$ & Liquid & 970 & 0.67 & 4.19 & 4064 \\
\hline & Water $\left(40^{\circ} \mathrm{C}\right)$ & $1.6 € / \mathrm{m}^{3}$ & Liquid & 990 & 0.63 & 4.19 & 4148 \\
\hline & Water $\left(10^{\circ} \mathrm{C}\right)$ & $1.6 € / \mathrm{m}^{3}$ & Liquid & 1000 & 0.6 & 4.19 & 4190 \\
\hline
\end{tabular}

Figure 2 shows the best available SHMs according to their average volumetric specific heat capacity and thermal diffusivity. The relatively low thermal capacity of the SHSMs is usually balanced by their temperature swing during charge and release processes (stratification ability).

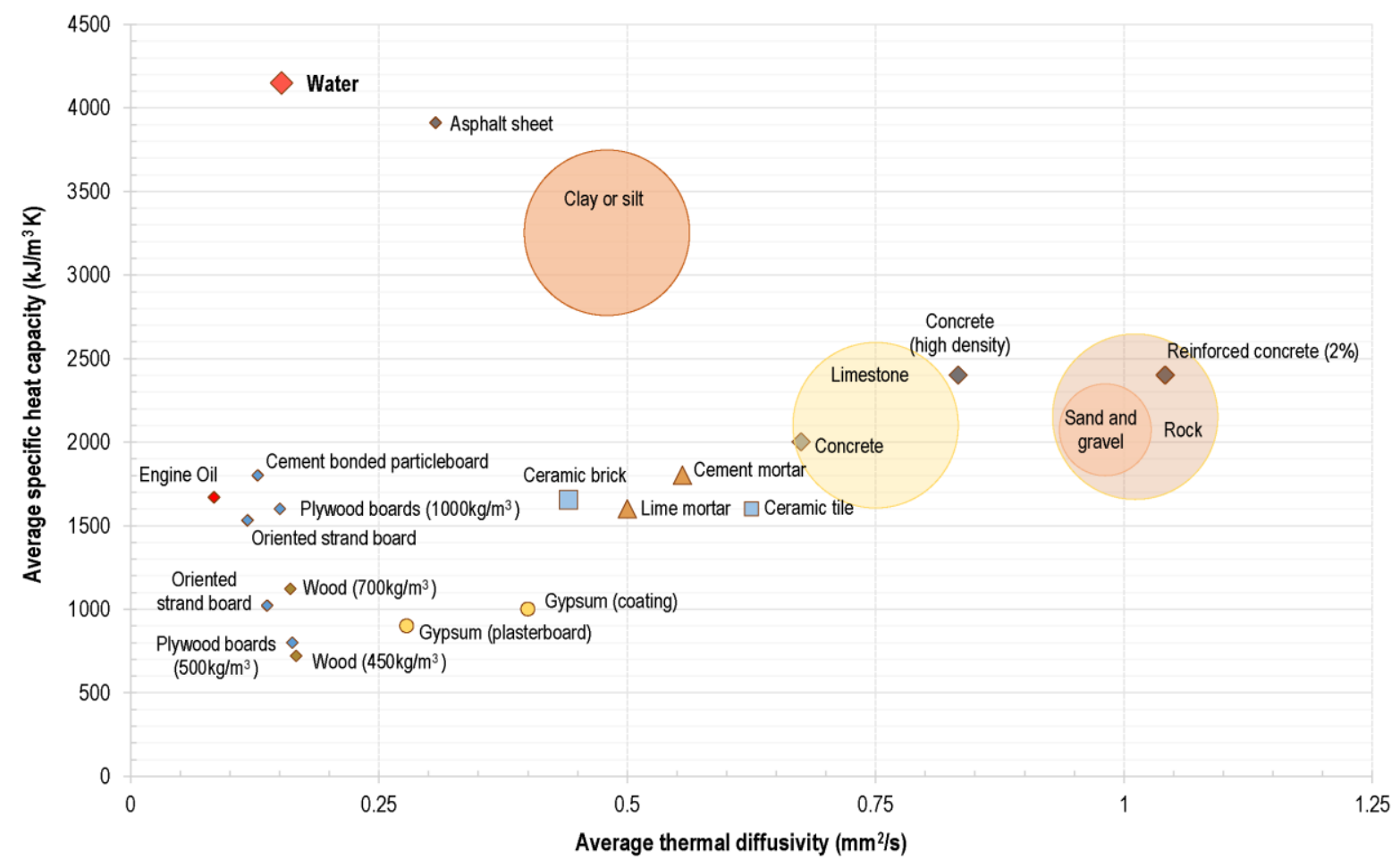

Figure 2. Common materials for sensible heat storage in building applications.

Regarding solid heat storage materials, the most commonly used ones are rocks, stones, bricks, concrete, dry and wet 
soil, wood, plasterboard, and corkboard [26], which are preferably employed for heating applications. Underground materials, such as rock, and dry and wet soil, can store heat up to $80^{\circ} \mathrm{C}$ with a volumetric storage capacity of approximately $108 \mathrm{MJ} / \mathrm{m}^{3}\left(\Delta \mathrm{T}=50^{\circ} \mathrm{C}\right)$. Concrete can operate in a temperature range from 30 to $70^{\circ} \mathrm{C}$ with a volumetric storage capacity around $95 \mathrm{MJ} / \mathrm{m}^{3}\left(\Delta \mathrm{T}=50^{\circ} \mathrm{C}\right)$. Despite the typically poor heat transfer by conduction between solid materials, stratification can be maintained over considerable time periods (Figure 2) [6]. Furthermore, underground solutions show the benefit of using the ground as an insulation medium, as in large-scale underground TES systems. However, the use of solids is limited by some issues such as reduced energy storage density as compared to water, relatively high costs of operation and maintenance of the storage units and risks of self-discharge in the long-term.

Regarding liquid storage materials, the most common materials are water or oils, and either pure alcohol or derivatives. They are widely used for cooling and heating purposes. Water is the best available liquid material employed due to its high specific heat capacity, availability and low cost [6], with a volumetric storage capacity of $250 \mathrm{MJ} / \mathrm{m}^{3}$ for heating purposes $\left(\Delta T=60^{\circ} \mathrm{C}\right)$ and $63 \mathrm{MJ} / \mathrm{m}^{3}$ for cooling applications $\left(\Delta T=15^{\circ} \mathrm{C}\right)$. The main drawbacks are the high investment cost for liquid storage infrastructures and the risk of leakages.

\subsection{Potential building applications based on sensible heat storage towards ZEBs.}

Most promising solutions based on sensible heat storage consist of high thermal inertia elements for passive applications, TABs, small-scale water tanks and large-scale seasonal TES systems.

- High thermal inertia elements based on sensible heat storage have been effectively implemented in buildings to attenuate indoor temperature fluctuations [36]. Karlsson et al. [37]evaluated the effects of increasing the TES capacity of building materials through a sensitivity analysis and showed that, for thin internal walls, implementing materials with high volumetric heat capacity can significantly reduce heat consumption and improve thermal comfort. In addition, it was reported that high thermal mass can significantly change the power consumption pattern, which would yield significant benefits. Rempel et al. [38] evaluated different passive applications, such us exposed mass walls, trombe walls or direct-gain floors, based on different sensible storage materials and design strategies focused on storing or delivering heat according to the building operating pattern. They demonstrated that despite passive elements cannot provide the instant heat or cooling as a mechanical system, they are adjustable by varying the material, thickness and configuration, and therefore can be defined according to users' requirements and daily space-heating (or cooling) needs. In addition, peak transmission loads can be reduced in summer and winter months by increasing the thermal inertia of the building. In intermediate months, cooling and heating energy needs can be decreased [39]. Al-Sanea et al. [39]investigated the effects of varying amounts of thermal mass of insulated building walls with same nominal resistance at different locations and demonstrated that wall dynamic resistance changes according to wall design despite nominal resistance is constant, and it represents actual variations in transmission loads. Thus, optimizing thermal mass for the same nominal resistance value, leads to higher savings in yearly transmission loads (about $17 \%$ for cooling and $35 \%$ for heating). In addition, Al-Sanea et al. showed that, for a given TES capacity, a wall with outside insulation yields better overall performance than a wall with inside insulation in applications with continuously operating year-round HVAC systems. However, it should be considered that there are applications in which adding sensible heat storage would not offer substantial benefits. Karlsson et al. [37] and Bloomfield and Fisk [40] evaluated the influence of thermal mass on building performance and concluded that the additional TES capacity of heavy-weight buildings do not offer any substantial improvements. They also reported that in cases with intermittently heated buildings, high thermal inertia is a clear disadvantage.

- TABs through sensible heat storage have been widely implemented to improve thermal management in buildings. Kim and Norford [41] evaluated the operation performance of variable speed heat pumps using the building structure as a TABs to improve power system operation by providing demand-side flexibility in cooling application. The results showed that the TABs solution achieved smaller operating costs than the convective cooling. In addition, Arteconi et al. [42] showed that a TABs can undersize the heating and/or cooling system by about $70-80 \%$. However, a continuous energy demand pattern is required for their effective implementation [8].

- Small-scale water tanks are the most commonly employed sensible TES application in buildings. However, it 
requires a large size for daily-weekly storage, and mainly for seasonal solar energy storage, which increases heat losses and reduces efficiency. For instance, water volume for covering annual heating needs of an energy efficient passive house, which is estimated in $6480 \mathrm{MJ}$ [6], is approximately $30-35 \mathrm{~m}^{3}$. On the other hand, a promising operation mode of small-scale sensible storage in water is based on demand-side management (DSM) applications [43]. DSM consists of a TES unit linked to a heating or cooling system, such as a heat pump, which takes advantage of off-peak tariff periods and other sub-optimal times (e.g., better exterior conditions). Renaldi et al. [44] showed that the integration of water storage and off-peak tariff periods reduces the annual operation cost by around $29 \%$.

- Large-scale seasonal solar energy storage in underground thermal energy storage (UTES) systems based on water, rock and soil materials is a mature technology that has been implemented and evaluated in many pilot plants in district heating networks [45-47] such as Drake Landing Solar Community DH system in Okotoks (Canada), which provides a solar fraction over 90\% [48]. Large-scale UTES systems help the integration of solar thermal energy by storing the energy excess produced in availability periods, thus enhancing the solar contribution $[5,49,50]$. Rapantova et al. [51] assessed long-term operation effects in the field of a borehole TES system, showing that seasonal underground storage can be feasible with a heat recovery of $65 \%$. According to European LargeScale Solar Heating Plant Database [52], underground water tanks and borehole TES are the most common systems in Europe, followed by aquifers and pit TES [52]. However, despite the fact that approximately 5000 thermal districts have been implemented in Europe [12], providing around 9-10\% of the EU's energy needs [3], large-scale solar DH networks are just around $3.2 \%[3,13]$. New research is required to demonstrate their economic viability [53], mainly for warm or mild climates, in order to further cut down investment costs and heat distribution costs [54]. Lizana et al. [55] reported that following specific sizing and design strategies for solar DH systems with BTES in Mediterranean areas, with high solar thermal energy availability, internal rates of return higher than $9.8 \%$ and a payback period below 10 years could be achieved.

Taking into account all sensible heat storage materials and applications assessed above, it may be concluded that water and underground materials stand as the most promising on the road to ZEBs due to their high sensible heat storage capacity and moderate thermal diffusivity. Their application in solar energy storage solutions and demand-side management strategies yield an efficient reduction of energy consumption in buildings. Furthermore, specific building designs making use of elements with high thermal inertia can yield significant benefits, albeit specific requirements should be addressed for their effective application.

\section{Latent heat storage materials}

This section describes the best available TES materials for building applications based on latent heat storage according to most recent publications, commercial data and reports from main PCM companies.

\subsection{Classification and characterisation parameters.}

Solid-liquid PCMs are the most commonly employed solutions in buildings [14]. These PCMs are classified into organic compounds, inorganic compounds and eutectics mixtures (mixtures between diverse inorganic and/or organic materials) [56-58]. Each one of these groups can be further categorised into diverse subgroups as shown in Figure 3.

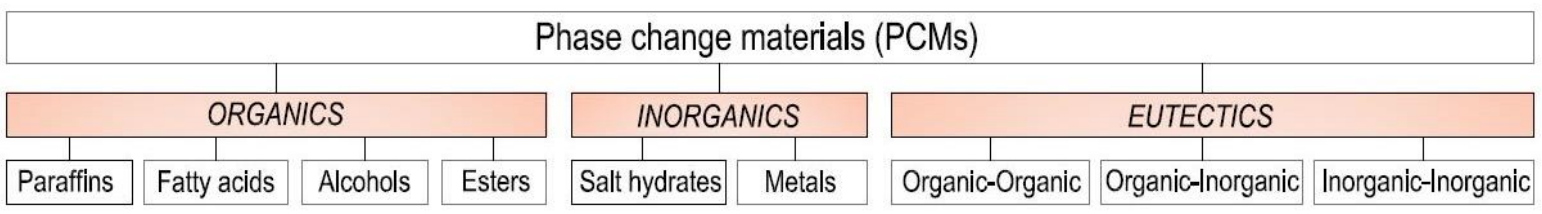

Figure 3. Classification of solid-liquid PCMs.

The thermodynamic, physical, kinetic, chemical and economic parameters of PCMs are listed in Table $3[14,59,60]$. Thermal reliability (no change in thermal properties), chemical stability (no phase segregation or changes in chemical composition), thermal stability at high temperatures after a large number of thermal cycles (no degradation or weight loss) 
and congruent melting (melting and solidification in a narrow temperature range without subcooling/supercooling) should be guaranteed to assure applicability and long life-time [14,56,59,61]. According to Harikrishnan et al. [61], stability would be required for approximately 5000 cycles for around 13-14 years.

Table 3. Characterisation parameters of solid-liquid PCMs.

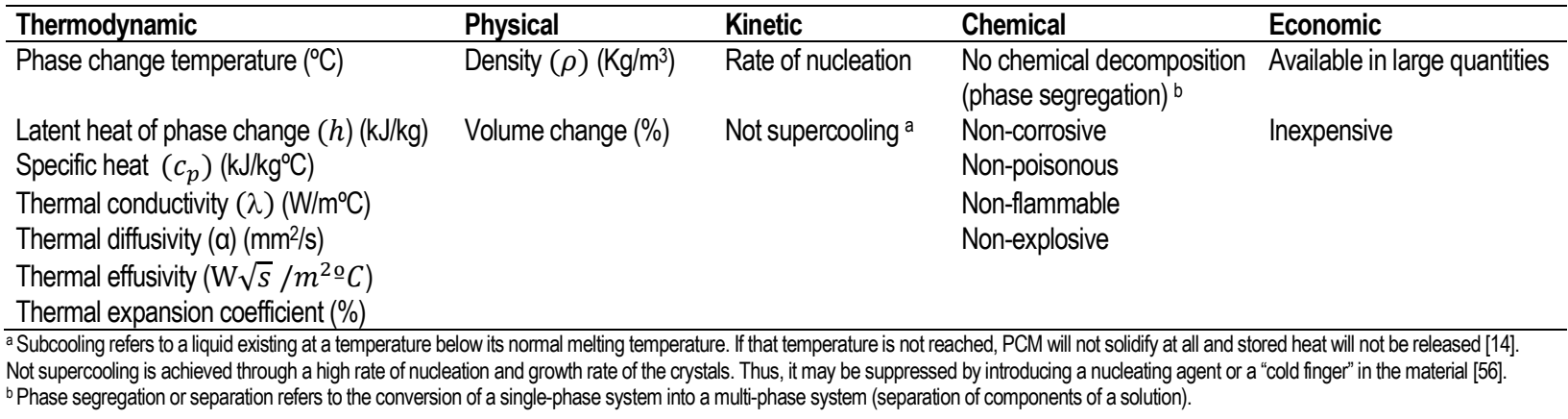

The total amount of energy stored $(Q)$ as latent heat along with the sensible heat stored in each physical state of a mass of material $(m)$ is given by Eq. 4 [28-30]. High specific heat in each physical state $\left(c_{p_{s}}\right.$ and $\left.c_{p_{l}}\right)$, high density, and high latent heat of fusion $\left(\Delta h_{f}\right)$ should be pursued to achieve a high storage density $\left(\mathrm{MJ} / \mathrm{m}^{3}\right)$.

$$
Q=m\left[\left(\int_{T i}^{T m} c_{p_{s}} d T\right)_{\text {sensible }}+\left(\Delta h_{f}\right)_{\text {latent }}+\left(\int_{T m}^{T f} c_{p_{l}} d T\right)_{\text {sensible }}\right](M J)
$$

According to the particular application, the selected material would depend on the suitable phase change temperature. In addition, the charging/discharging periods and power depend on thermal conductivity, exchange flowrate and thermal diffusivity. Small volume change, availability, low cost and non-toxicity are also relevant material properties in practice [57]. Most common drawbacks of PCMs are linked to their high cost, low thermal conductivity, relative large volume change, flammability, supercooling, corrosiveness, and thermal reliability and stability after undergoing a great number of thermal cycles [57].

\subsection{Assessment of available latent heat storage materials.}

Paraffins, salt hydrates and eutectic mixtures are the main PCMs for building applications $[57,60]$ :

- Paraffins are a mixture of pure alkanes obeying the chemical formula $\mathrm{C}_{n} \mathrm{H}_{2 n+2}$, where $20 \leq n \leq 30$. They show favourable properties for building applications, such as negligible supercooling, non-corrosiveness, chemical stability, no phase segregation and low cost $[6,56,62-64]$. Their main drawbacks are related to their low volumetric latent heat storage capacity, low thermal conductivity and flammability [58]. Their average latent heat capacity is approximately $170 \mathrm{MJ} / \mathrm{m}^{3}$ and the average thermal conductivity is about $0.2 \mathrm{~W} / \mathrm{m}^{\circ} \mathrm{C}[57]$.

- Salt hydrates are alloys of inorganics salts $(\mathrm{AB})$ and water $\left(\mathrm{H}_{2}\right)$ with a chemical formula $\mathrm{AB} \cdot \mathrm{xH}_{2} \mathrm{O}$. They have relatively high latent heat capacity and thermal conductivity (approximately $350 \mathrm{MJ} / \mathrm{m}^{3}$ and $0.5 \mathrm{~W} / \mathrm{m}^{\circ} \mathrm{C}$, respectively) [57]. Moreover, salt hydrates are cheaper than paraffins [60] and non-flammable [58]. Thus, they show a higher potential for applicability in buildings [65] albeit with some disadvantages such as their low thermal reliability for long-operation periods [29], phase segregation, subcooling and corrosiveness $[6,58,63,66]$.

- Eutectics (chemical formula: A compound + B compound) are mixtures of inorganic PCMs (mostly hydrated salts) and/or organic PCMs. They have a melting temperature below those of the constitutive compounds [60]. In addition, eutectic alloys present a congruent phase change without phase segregation [6].

Fatty acids, esters and alcohols are usually highly flammable and have low thermal conductivity with diverse levels of toxicity [29], which limits their application in buildings. Regarding the use of metals in the range of temperatures of interest, poor availability and very high cost limit their application in buildings despite having a high thermal conductivity [6] and volumetric fusion heat due to their high density [29]. 
Currently, there are more than 250 commercially available PCMs in the temperature range between $-10^{\circ} \mathrm{C}$ and $+120^{\circ} \mathrm{C}$. They can be obtained from the main existing companies listed in Table 4. Properties of these materials are shown in Appendix A (Tables A1-8). They are mainly based on paraffins, salt hydrates and eutectic alloys. The average cost of PCMs is approximately $6 € / \mathrm{kg}$, ranging from $40 € / \mathrm{kg}$ to $3.6 € / \mathrm{kg}$ for wholesale orders [67-69].

Table 4. Commercial PCMs and main supplying companies around the world.

\begin{tabular}{|c|c|c|c|}
\hline Company & Country of origin & Classification of materials & Product ID \\
\hline \multirow[t]{4}{*}{ Rubitherm GmbH [70] } & Germany & Organic PCMs - Paraffins & RT \\
\hline & & Inorganic PCMs - Salt hydrates & SP \\
\hline & & Powder & PX \\
\hline & & Granules & GR \\
\hline Climator [71] & Sweden & Salt hydrates & ClimSel C \\
\hline \multirow[t]{2}{*}{ Cristopia Energy Systems [72,73] } & India and France & Air conditioning & $A C$ \\
\hline & & Industrial refrigeration & IN \\
\hline PCM Energy [74] & India & Salt hydrates & Latest $^{\mathrm{TM}}$ \\
\hline \multirow[t]{5}{*}{ PCM Products Ltd [75] } & UK & Sub Zero Eutectics & $E$ \\
\hline & & Salt Hydrates & $S$ \\
\hline & & Organic PCMs & A \\
\hline & & Salt PCMs & $\mathrm{H}$ \\
\hline & & Solid/Solid PCMs & $\mathrm{X}$ \\
\hline BASF - Micronal PCM [76] & Germany & Powders & DS \\
\hline \multirow[t]{3}{*}{ RGees. savENRG ${ }^{\mathrm{TM}}$ [77] } & USA & Inorganic PCMs (hydrated salts) & PCM-HS \\
\hline & & Organic PCMs & PCM-OM \\
\hline & & Bio-based PCM (fatty acids) & - \\
\hline Entropy solutions. PureTemp [69] & USA & Organic PCMs & PureTemp \\
\hline
\end{tabular}

The relationship between the volumetric latent heat density and the melting temperature of commercially available PCMs in the market is illustrated in Figure 4. Sensible heat storage in water at different temperatures for heating and cooling is shown as reference (yellow line). 


\section{Eutectics}

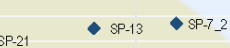

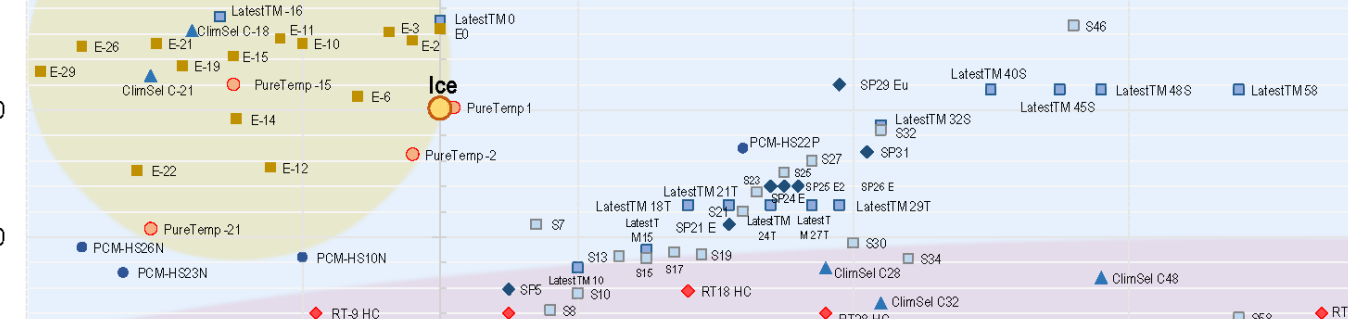

150

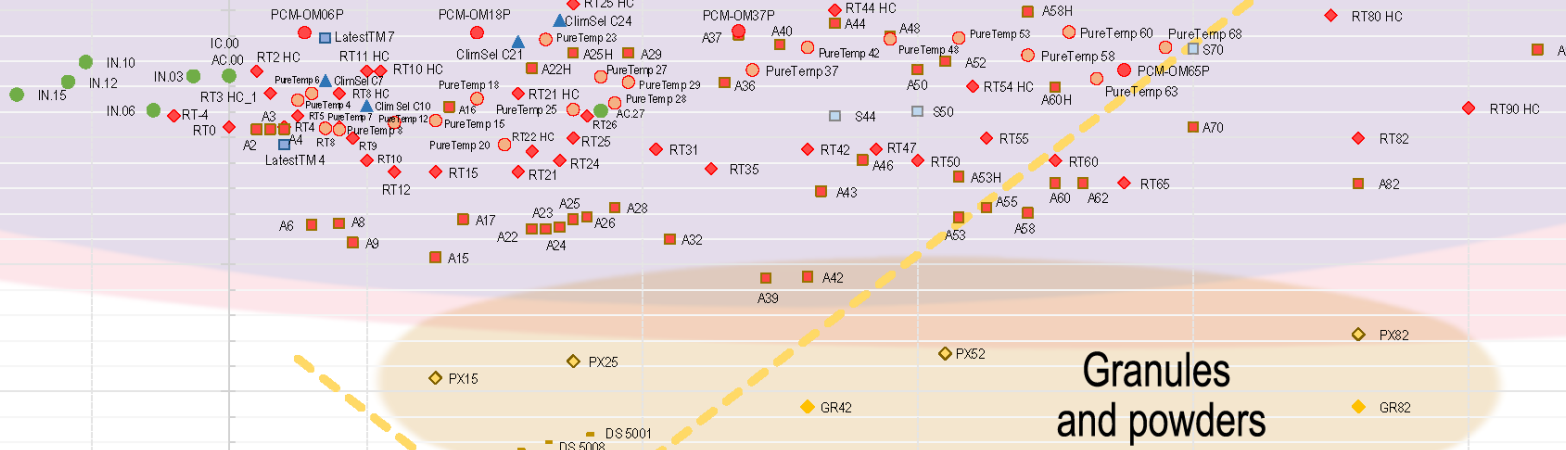

\section{$\checkmark \times \times 52 \quad$ Granules} and powders

50

- Rubitherm. Organic PCMs - Cristopia Energy Systems

- Rubitherm. Inorganic PCMs - PCM Energy. Hydrated salts - Rgees. Hydrated salts ${ }^{*}$ Ihe dashed line corresponds to sensible storage in water as reterence material. Figure 4. Commercially available PCMs for building applications.
- Rubitherm. Powder

- PCM Products. Eutectic PCMs

- Rgees. Organic PCMs
Meelting temperature $\left.{ }^{\circ} \mathrm{C}\right)$

Sensible storage in water

a82

PX82

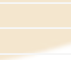

Rubitherm Granules

PCM Products. Hydrated salts

- PureTemp. Organic PCMs
- Climator Salt hydrates - PCM Products. Organic PCMs 
The volumetric latent heat density of commercially available inorganic materials (blue symbols in Fig. 4) ranges between 150 and $430 \mathrm{MJ} / \mathrm{m}^{3}$. On the other hand, the volumetric latent heat capacity of available organic materials belongs to a lower range, between 100 and $250 \mathrm{MJ} / \mathrm{m}^{3}$ (red colour marks). Sensible heat storage in water, which can be used as reference, has a capacity ranging from 63 to $250 \mathrm{MJ} / \mathrm{m}^{3}$ for cooling and heating purposes, respectively.

\subsection{Potential building applications based on PCMs towards ZEBs.}

Most promising solutions based on latent heat storage consist of passive applications, encapsulated PCM into freecooling ventilation systems, and small-scale TES units for solar storage and DSM strategies.

- In passive applications, in order to keep a low weight and size of building components, PCMs are more suitable than sensible heat storage materials in a reduced temperature range. Ramakrishnan et al. [78] assessed the performance of building refurbishment through macro-encapsulated PCMs with a melting temperature and volumetric latent heat capacity of $29^{\circ} \mathrm{C}$ and $51.5 \mathrm{MJ} / \mathrm{m}^{3}$ respectively. Results showed that PCM combined with night ventilation can effectively reduce the severe discomfort period (discomfort index above $28^{\circ} \mathrm{C}$ ) by $65 \%$ during extreme heatwave conditions. Mi et al. [79] evaluated the economic performance of PCM passive application in five different cities of China. The melting temperature was $27^{\circ} \mathrm{C}$ and latent heat capacity of approximately $230 \mathrm{~kJ} / \mathrm{kg}$. Test results showed that the energy savings and economic benefits are more prominent for office buildings located in cold regions, as well as in regions with hot summers and cold winters. In these situations, a static payback period from 5 to 7 years was achieved. However, at current prices, the PCM investment cannot be recovered in regions with a relatively moderate climate, with no chilly winters and hot summers. Castell et al. [80] showed energy savings higher than 15\% with macroencapsulated PCM applications in buildings, and Cabeza et al. [81] showed that peak temperatures can be reduced by approximately $1-2^{\circ} \mathrm{C}$ by introducing microencapsulated PCMs into concrete walls. However, life-cycle assessment evaluation of PCM solutions showed that, although these solutions decrease the energy consumption during operation, they do not significantly reduce the global impact throughout the lifetime of buildings $[82,83]$. Thus, additional research has to be pursued in order to extend the use of PCMs, mainly by reducing material cost [84] and by achieving higher storage capacity.

- TES components for ventilation systems represent an attractive alternative to air-conducing units. They reduce overheating during the summer periods by using low night temperatures [8] although solutions can only be implemented in climate areas where night-day temperature oscillation ranges from $12^{\circ} \mathrm{C}$ to $15^{\circ} \mathrm{C}$ [22]. Commercial solutions are available, such as the Cool-Phase systems from Monodraught Ltd (UK Company) [85], based on macroencapsulated PCMs to regulate indoor temperatures up to $\pm 4^{\circ} \mathrm{C}$ and reduce energy consumption by up to $90 \%$ according to commercial specifications [86].

- Small-scale TES units based on PCMs allow for higher volumetric heat capacity than sensible heat storage for solar thermal and DSM strategies [6]. Thus, higher energy and economic benefits can be achieved through more compact storage solutions. Cui et al. [87] evaluated the performance of a demand management strategy based on an HVAC system integrated with an active cool TES for commercial buildings. The cool TES unit was designed with a relatively small scale, up to $6.7 \%$ of typical daily cooling load, and was based on a PCM with a melting temperature of $8^{\circ} \mathrm{C}$ and volumetric latent heat capacity of $205.7 \mathrm{MJ} / \mathrm{m}^{3}$. The results showed that cool TES implementation for shifting peak demand, as well as providing longer duration and larger capacity for demand response, can achieve a pay-back period of 8.6 years. However, a main challenge for a viable implementation is the high investment costs. Campos-Celador et al. [67] developed a latent heat storage prototype with a storage volume reduced by approximately $50 \%$ compared with a conventional water tank. Investment cost was around $805 €$ for $8.5 \mathrm{kWh}$ storage capacity (not including manufacturing and commercial costs). Taking into account that the PCM represented approximately $75 \%$ of the prototype cost, a main challenge for their deployment would be a reduction of the material cost. 
By considering all latent heat storage materials and applications assessed, it can be concluded that PCMs based on hydrated salts are the best choice due to their high volumetric latent heat storage capacity, moderate thermal conductivity and low-moderate cost. In addition, their applications in free-cooling ventilation systems, solar energy storage solutions, and demand-side management strategies are in tune with the road to zero energy buildings mainly due to the effective optimization of the amount of required material and operating conditions. On the other hand, latent heat storage in passive applications requires specific climate conditions and operating patterns to effectively improve the building thermal performance.

\section{Thermochemical energy storage materials}

In this section, the best available TES materials for building applications based on thermochemical energy storage are analysed from a review of the recent $R \& D$ activities, publications and projects.

\subsection{Classification and characterisation parameters}

Thermochemical energy storage is a wide concept that refers to sorption processes and chemical reactions [17]. A chemical reaction is characterised by a change in the chemical bonds of the compounds involved in the reaction (dissociation and recombination) [6]. Energy can be stored through the endothermic reaction and released by the reverse exothermic reaction, sometimes by adding a catalyst [6]. Sorption storage can be defined as a phenomenon of fixation or capture of a gas or a vapour by a sorbent substance in a condensed state (solid or liquid) by means of less intense physical interactions [18]. Sorption processes may have either a thermo-physical or a thermo-chemical nature.

A classification of tested thermochemical storage materials (TSMs) in the literature is illustrated in Figure 5. TSMs are grouped according to the process involved: physical adsorption (zeolite and silica gel), liquid absorption or chemical reaction. A separate category consists of composite materials (CSMP) $[17,18]$.

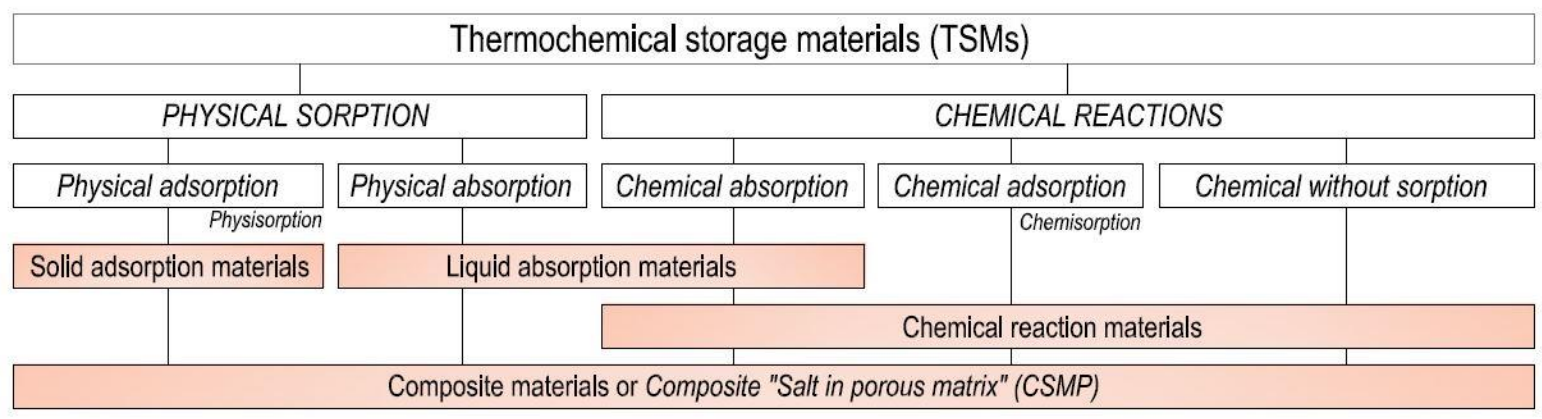

Figure 5. Classification of TSMs for building applications.

Thermal storage sorption processes can be further classified into open or closed systems. Open cycle systems operate at atmospheric pressure and vapour, as the working fluid is released into the surroundings, which means that only water processes are used. In contrast, closed cycles operate in isolation from the surrounding environment in closed circuits.

The thermodynamic, physical, kinetic, chemical and economic parameters of TSMs are listed in Table 5. Moreover, thermal reliability (no change in thermal properties), chemical stability (no change in chemical composition) and thermal stability at high temperatures (no degradation or weight loss), after a large number of thermal cycles, must be guaranteed to assure a viable application and long life-time.

Table 5. Characterisation parameters of TSMs.

\begin{tabular}{|c|c|c|c|c|}
\hline Thermodynamic & Physical & Kinetic & Chemical & Economic \\
\hline Charging/desorption temperature $\left({ }^{\circ} \mathrm{C}\right)$ & Density $(\rho)$ & Kinetic of reaction $(\mathrm{m} / \mathrm{s})$ & No chemical decomposition & Available in large quantities \\
\hline Discharging/sorption temperature $\left({ }^{\circ} \mathrm{C}\right)$ & Operating pressure $(\mathrm{Pa})$ & & Non-corrosive & Inexpensive \\
\hline Heat input (Wh/kg) & Degree of sorbate loading ( $\%)$ & & Non-poisonous & \\
\hline Heat output (Wh/kg) & Volume change (\%) & & Non-flammable & \\
\hline Storage efficiency ( $Q_{\text {released }} / Q_{\text {stored }}$ ) & & & Non-explosive & \\
\hline
\end{tabular}


The total amount of energy stored $(Q)$ through thermochemical processes is given by Eq. 5 [30]. High density, high energy storage density $(\mathrm{Wh} / \mathrm{kg})$ and high storage efficiency $\left(\mathrm{Q}_{\text {released }} / \mathrm{Q}_{\text {stored }}\right)$ should be the goals to achieve a high volumetric storage capacity $\left(\mathrm{MJ} / \mathrm{m}^{3}\right)$.

$$
C_{1} C_{2}+\text { Heat input } \Rightarrow C_{1}+C_{2} \Rightarrow \text { storage } \rightrightarrows C_{1}+C_{2} \Rightarrow C_{1} C_{2}+\text { Heat output }
$$

According to the particular application, a suitable charging/discharging temperature should firstly be established. Charging/discharging periods and power depend mainly on operating pressure, reaction kinetics, thermal conductivity and exchange flowrate. Small volume change, availability, low cost and environmental impact are also important properties to take into consideration.

The main drawbacks of TSMs are related to their high cost, inappropriate operation temperatures, non-effective discharge power for building applications, due to slow reaction kinetics and low output temperature close to the equilibrium point, as well as low/moderate efficiency in storage process $[18,84]$.

\subsection{Evaluation of available thermochemical storage materials.}

Research and development in thermochemical energy storage remains at an early stage for building applications [6]. The high cost of materials, poor heat and mass transfer capacity, and system energy density substantially, lower than material energy density, are the main barriers for deployment [18]. Materials under research for building applications are mainly focused on solar energy storage solutions for long-term storage $[17,88]$.

Most promising TSMs have been tested through coordinated international programmes and projects $[17,18,88]$. Some of these studies are related to Task 32 (2003-2007) [89,90] and Task 42 (2009-2015) [19] in the framework of the Solar Heating and Cooling Programme of the International Energy Agency (SHC-ECES) [91]. Others are related to European projects such as HYDES, MODESTORE (2003-2012), MERITS (2007-20013), COMTES (2012-2016) or E-HUB (20102014). Table 6 shows performance results of tested TSMs for building applications. Figure 6 illustrates volumetric storage capacity and charging/desorption temperatures of reported TSMs. Sensible heat storage in water is shown as reference.

Silica gel 127B and zeolites (4A, 5A, 13X and $\mathrm{NaX}$ ) have been tested in open and closed physical adsorption cycles. Silica gel 127B/ $\mathrm{H}_{2} \mathrm{O}$ has been studied in a closed adsorption cycle within the HYDES and MODESTORE projects (20032012). The results showed that the silica gel/water system has to operate with water contents of 3-13\%, which hinders its actual TES capacity. Thus, to achieve a practical seasonal energy storage capacity, large storage volumes are necessary. Zeolite $13 \mathrm{X}$ has been identified as one of the best adsorbents due to its high water uptake, which provides a high energy storage density. This material has attracted the interest of researchers. Most of the current demonstration projects are based on zeolite 13X, such as the E-Hub project (2010-2014) or COMTES project (2012-2016). In addition, novel solid porous materials for adsorption processes have been proposed for TES applications, such as aluminophosphates (AIPOs), silico-aluminophosphates (SAPOs) and metal-organic frameworks (MOFs). However, their high production cost is a main barrier for implementation [17].

Liquid materials such as $\mathrm{LiCl}, \mathrm{NaOH}, \mathrm{CaCl}_{2}$ and $\mathrm{LiBr}$ have been tested in closed absorption cycles [19,89,92-94]. These aqueous absorption materials present higher energy density values than solid adsorption materials, with temperatures in a proper range for building applications. Also, liquid desiccants can be pumped to be used directly as heat transfer fluid [95].

Chemical reaction materials such as magnesium sulphate $\left(\mathrm{MgSO}_{4}\right)$ or calcium chloride $\left(\mathrm{CaCl}_{2}\right)$, which have a relatively high energy storage density, have been also tested. However, very slow reaction rates associated with a low temperature lift in the reactor [96] and low chemical stability after cycling [97] are the main drawbacks. In order to improve chemical 
storage material properties, and particularly to enhance the reaction rate and heat release, a new family of composite sorbents, called Composite "salt porous matrix" (CSPM), has been recently proposed [98]. These composite materials are based on two sorbents: the host matrix (zeolite, silica gel, alumina, expanded vermiculite, aerogel, etc.) with porous structure and high thermal conductivity to improve the reaction rate and thus the heat release, and an inorganic salt solution ( $\mathrm{LiCl}, \mathrm{CaCl}_{2}, \mathrm{MgCl}_{2}, \mathrm{MgSO}_{4}, \mathrm{Ca}\left(\mathrm{NO}_{3}\right)_{2}, \mathrm{LiNO}_{3}$, etc.), placed inside the matrix, which further enhances the energy storage. 
Table 6. TSMs reported in the literature for building applications.

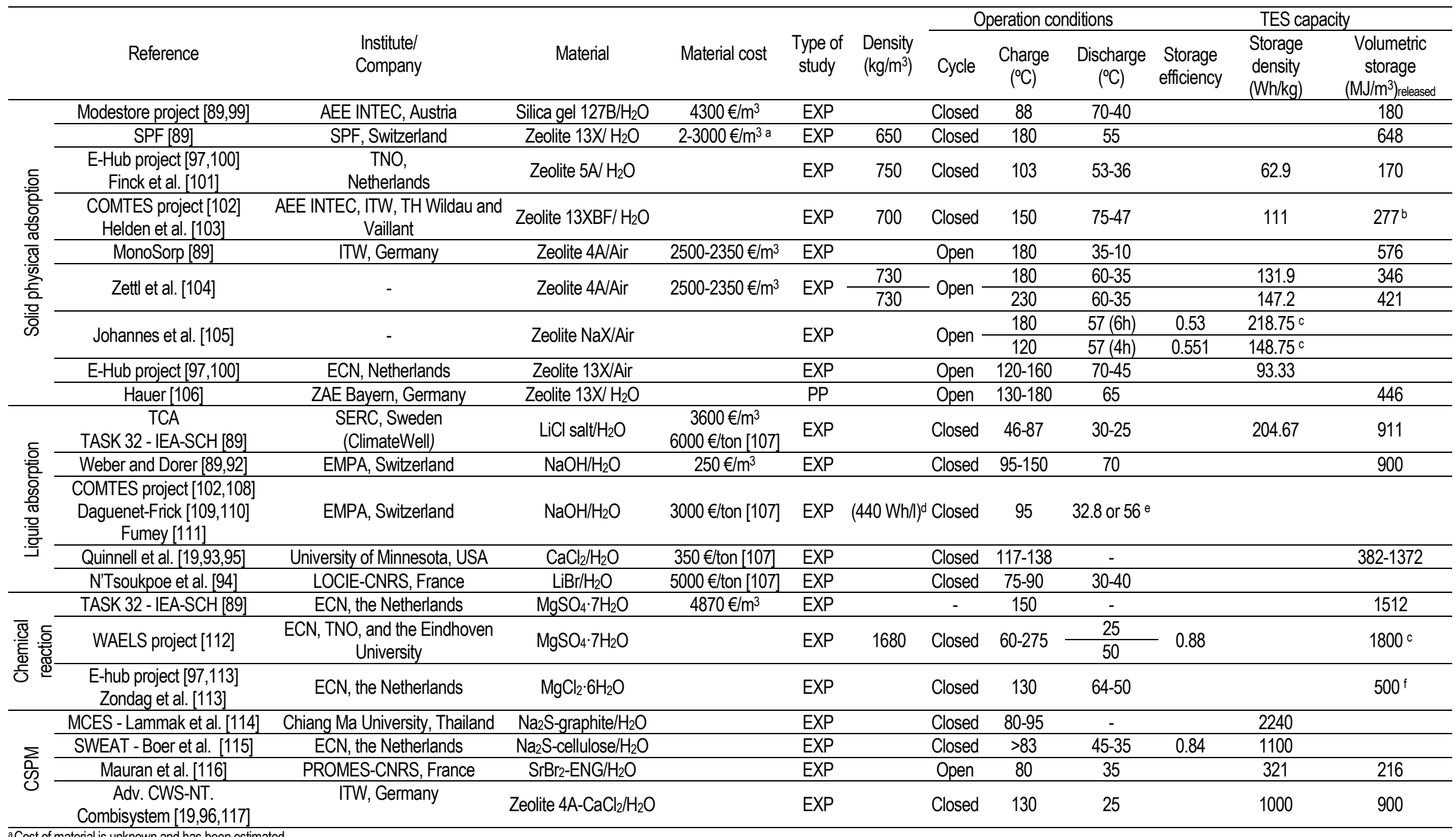

Cost of material is unknown and has been estimated.

${ }^{b} 64 \%$ of the theoretical value, mainly due to the relative high residual water vapour content of the zeolite $(13 \%)$.

cRatio obtained by means of released energy.

${ }^{d}$ Experimental energy density of the material without taking efficiency losses into account.

eDischarging temperature in absorber for heating: $328^{\circ} \mathrm{C}$ (inlet flow at $14^{\circ} \mathrm{C}$ ). Discharging temperature in absorber for DHW: $56^{\circ} \mathrm{C}$ (inlet flow at $25^{\circ} \mathrm{C}$.

${ }^{\mathrm{E} E f f e c t i v e ~ s t o r a g e ~ d e n s i t y ~ o f ~ t h e ~ m a t e r i a l ~ b y ~ t a k i n g ~ i n t o ~ c o n s i d e r a t i o n ~ h e a t ~ l o s s e s ~ i n ~ t h e ~ t h e r m o c h e m i c a l ~ s t o r a g e ~ p r o c e s s . ~}$ 


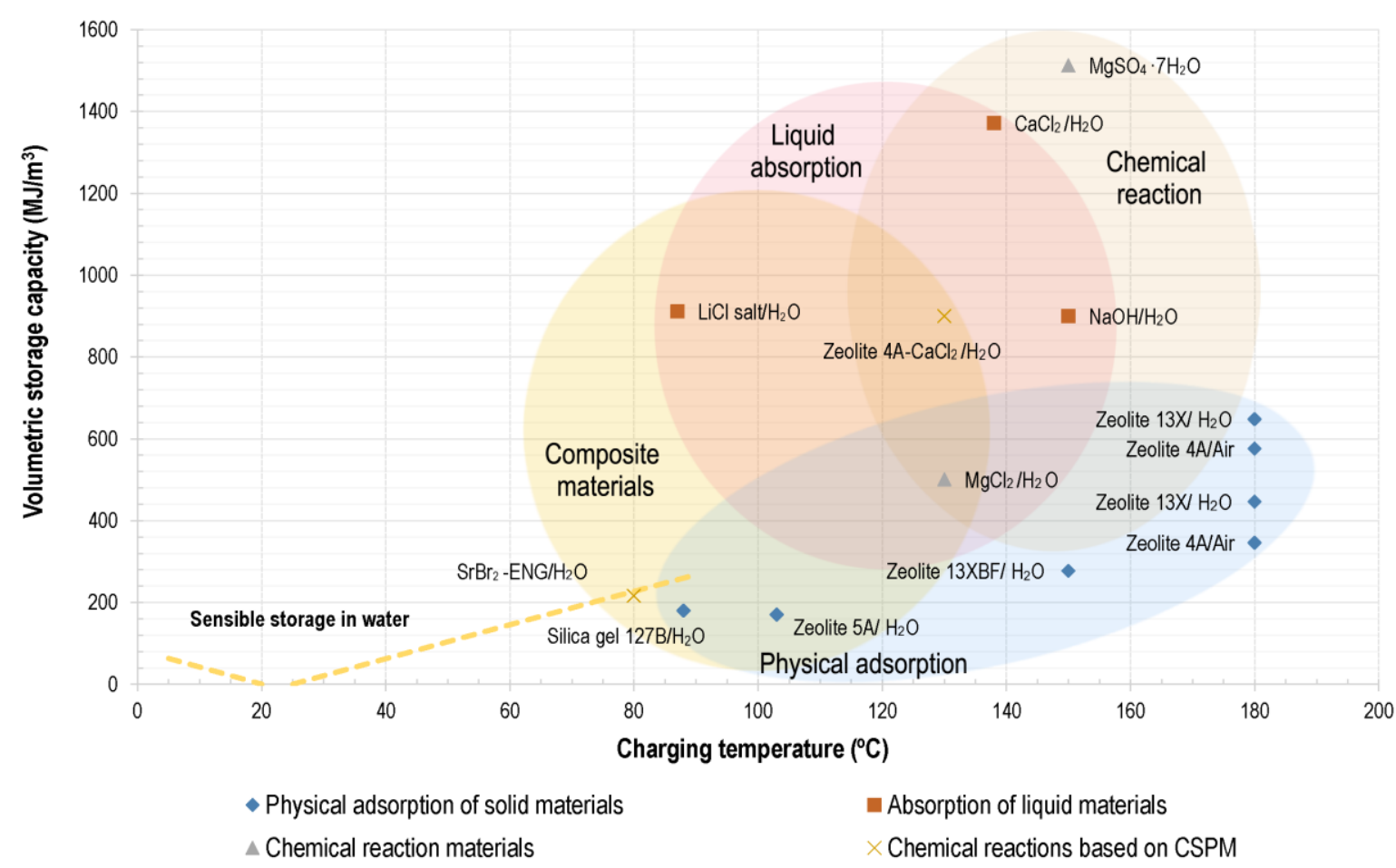

* The dashed line corresponds to sensible heat storage in water to be taken as reference.

Figure 6. Thermochemical energy storage materials for building applications.

Taking into account all reported TSMs, and despite their high energy density, to date there is no available material that satisfies all requirements for efficient thermochemical energy storage in the building sector. High cost, low discharge capacities, variable thermal power over time, and poor thermal stability and reliability through cycling are main challenges for research.

\subsection{Potential building applications based on thermochemical energy storage towards ZEBs.}

Today, thermochemical applications for TES are not available as commercial solutions in buildings. Different smallmedium scale heat storage prototypes based on physical sorption and chemical reactions are found in the literature $[17,18,88,118]$ and in reports from international programmes and projects $[19,89,90]$. Reported prototypes show limitations in heat and mass transfer and reaction kinetics, as well as in the extra volume of components required to add and extract energy from the storage vessel [19], which considerably reduce the volumetric storage capacity, thus hampering viability for building implementation. Final prototype energy density is often significantly below the material storage density, usually by more than $50 \%$ [18]. Additional efforts are needed to optimise material costs and systems design. 


\section{Discussion of results. Drawbacks, advantages and challenges}

Figure 7 illustrates the ranges of volumetric TES capacity of technically developed and commercially available material groups.

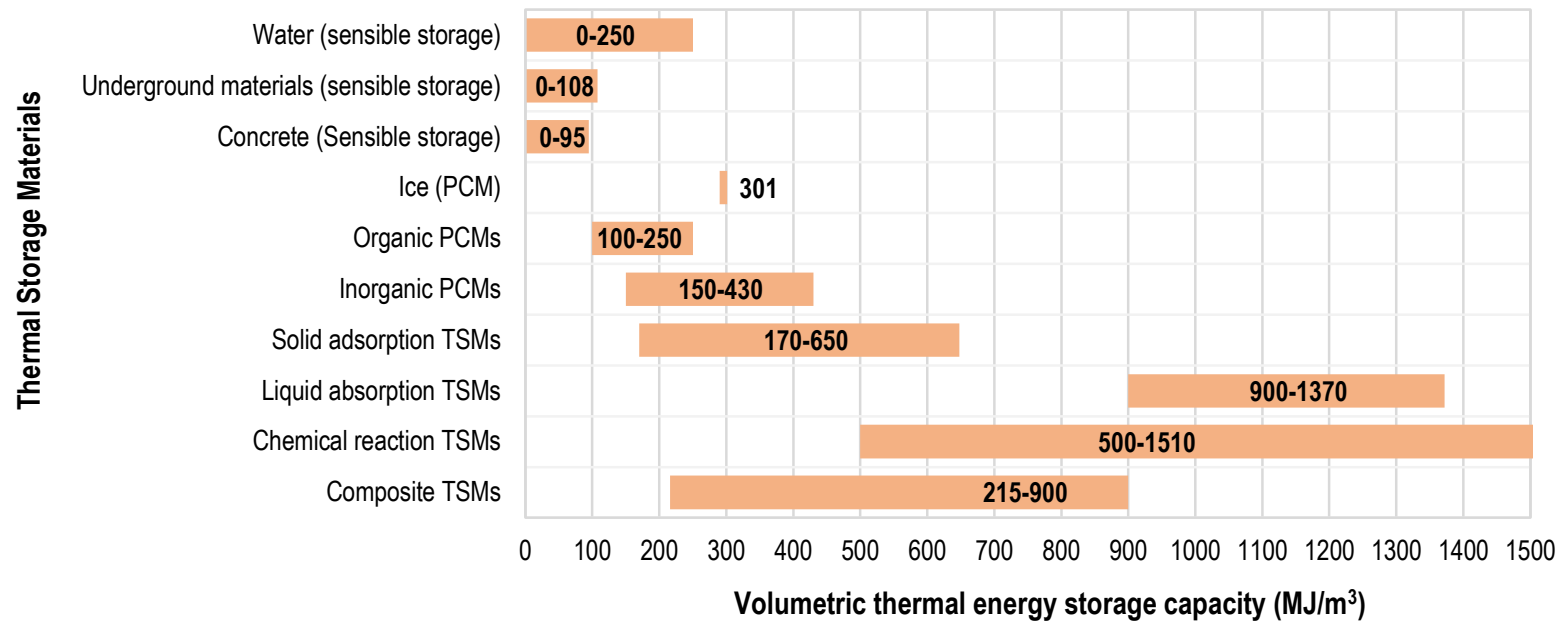

Figure 7. Comparison of volumetric storage capacity of thermal storage materials reviewed in this work.

Water storage through sensible (liquid) and latent heat (ice) have a volumetric storage capacity of 250 and $301 \mathrm{MJ} / \mathrm{m}^{3}$, for heating and cooling purposes, respectively. Low cost and wide availability makes this solution highly competitive.

Underground materials, such as rock, and dry and wet soil, have a volumetric storage capacity up to $108 \mathrm{MJ} / \mathrm{m}^{3}$ for heating applications. Their use allows effective solutions through large-scale UTES systems, since stratification in underground materials can be maintained over considerable time periods, materials cost is null, and underground solutions have the benefit of using the ground as insulation.

Organic and inorganic PCMs energy density is in the range $100-430 \mathrm{MJ} / \mathrm{m}^{3}$ for phase change temperatures between -10 and $+120^{\circ} \mathrm{C}$. More than 250 materials in this regard are currently available. However, the feasibility of latent heat applications could be improved if cheaper PCMs were available, as materials represent approximately $75 \%$ of system costs [67].

Thermochemical TES capacity ranges from 170 to $1510 \mathrm{MJ} / \mathrm{m}^{3}$. However, despite this high energy density, thermochemical-based TES units require additional components such as tanks and heat exchangers, which can reduce storage density by more than $50 \%$ [18]. Solutions require a considerable enlargement of storage systems to increase the energy density ratio of final units. In addition, the high investment cost of most of the materials successfully tested at the laboratory scale, from 350 to $3600 € / \mathrm{m}^{3}$, and further safety requirements, environmental impact, lifetime and compatibility constrain the application of thermochemical energy solutions in buildings.

Table 7 summarises the main selection criteria, disadvantages, advantages and challenges for each TES method according to the state-of-the-art reviewed in this work. Thermal, physical, kinetic, chemical and economic parameters for the selection of appropriate TES materials are proposed. These are average values considering all reported materials to seek the best possible performance in order to help the technical decision-making process for the design of energy efficiency applications towards ZEBs. 
Table 7. Selection criteria, drawbacks, advantages and challenges of TES materials.

\begin{tabular}{|c|c|c|c|c|c|}
\hline $\begin{array}{l}\text { TES } \\
\text { materials }\end{array}$ & Properties & Main selection criteria & Drawbacks & Advantages & Challenges \\
\hline \multirow[t]{4}{*}{ SHSMs } & Thermal & $\begin{array}{l}\text {-Specific heat capacity }>2000 \mathrm{~kJ} / \mathrm{m}^{3} \mathrm{~K} \\
\text {-Thermal conductivity }>0.6 \mathrm{~W} / \mathrm{m}^{\circ} \mathrm{C} \\
\text {-Thermal diffusivity }>0.5 \mathrm{~mm}^{2} / \mathrm{s}\end{array}$ & $\begin{array}{l}\text {-High heat losses } \\
\text {-Self-discharge } \\
\text {-Low storage density }\end{array}$ & -Easy stratification & $\begin{array}{l}\text {-Heat lost reduction } \\
\text {-Super insulation of units }\end{array}$ \\
\hline & Physical & - Density $>1000 \mathrm{~kg} / \mathrm{m}^{3}$ & -Huge volumes & -Pumpable liquid & \\
\hline & Chemical & -Compatibility & & $\begin{array}{l}\text {-Long-term stability and } \\
\text { reliability } \\
\text {-Environmentally friendly }\end{array}$ & \\
\hline & Economic & - Cost $<10 € / \mathrm{m}^{3}$ & -High construction cost & -Low cost & -Ultra-cheap storage \\
\hline \multirow[t]{5}{*}{ LHSMs } & Thermal & $\begin{array}{l}\text {-Suitable phase change temperature } \\
\text {-Phase change enthalpy }>200 \mathrm{~kJ} / \mathrm{kg} \\
\text {-Specific heat capacity in both phases } \\
>2000 \mathrm{~kJ} / \mathrm{m}^{3} \mathrm{~K} \\
\text {-Thermal conductivity in both phases }>0.6 \mathrm{~W} / \mathrm{m}^{\circ} \mathrm{C} \\
\text {-Thermal reliability }>90 \% \text { after } 5000 \text { cycles }\end{array}$ & $\begin{array}{l}\text {-Low thermal conductivity } \\
\text {-Different heat transfer in each } \\
\text { physical state. } \\
\text {-Low thermal stability and } \\
\text { reliability }\end{array}$ & $\begin{array}{l}\text {-High storage density in a } \\
\text { short temperature range } \\
\text {-Constant operating } \\
\text { temperature }\end{array}$ & $\begin{array}{l}\text {-Enhancement of thermal } \\
\text { conductivity. } \\
\text {-Higher thermal reliability. }\end{array}$ \\
\hline & Physical & $\begin{array}{l}- \text { Density }>1000 \mathrm{~kg} / \mathrm{m}^{3} \\
\text {-Low density variation }\end{array}$ & $\begin{array}{l}\text {-Not pumpable } \\
\text {-Volume change }\end{array}$ & -Greater design flexibility & $\begin{array}{l}\text {-Development of pumpable } \\
\text { materials }\end{array}$ \\
\hline & Kinetic & -Not subcooling & $\begin{array}{l}\text {-Subcooling } \\
\text {-Crystallisation }\end{array}$ & & \\
\hline & Chemical & $\begin{array}{l}\text {-Chemical stability after } 5000 \text { cycles } \\
\text {-Compatibility and security }\end{array}$ & $\begin{array}{l}\text {-Phase segregation } \\
\text {-Toxicity } \\
\text {-Corrosiveness }\end{array}$ & & -Higher chemical stability \\
\hline & Economic & - Cost $<8 € / \mathrm{kg}$ & -High cost & & -Low-cost solutions \\
\hline \multirow[t]{5}{*}{ TSMs } & Thermal & $\begin{array}{l}\text { - Suitable charging/discharging temperature } \\
\text {-Volumetric storage capacity > } 1000 \mathrm{MJ} / \mathrm{m}^{3} \\
\text {-Thermal transfer capacity } \\
\text {-Thermal reliability }>90 \% \text { after } 5000 \text { cycles }\end{array}$ & $\begin{array}{l}\text {-Poor heat and mass transfer } \\
\text { property under high-density } \\
\text { condition } \\
\text {-Thermal reliability } \\
\text {-Low volumetric storage } \\
\text { capacity of prototypes }\end{array}$ & $\begin{array}{l}\text {-High storage density } \\
\text {-Negligible heat losses }\end{array}$ & $\begin{array}{l}\text { - Improvement of thermal } \\
\text { transfer capacity. } \\
\text {-Knowledge of material } \\
\text { behaviour under realistic } \\
\text { conditions } \\
\text {-Higher storage capacity of } \\
\text { final solutions }\end{array}$ \\
\hline & Physical & -Low operating pressure & & & \\
\hline & Kinetic & -Kinetic of reaction & & & \\
\hline & Chemical & $\begin{array}{l}\text {-Chemical stability after } 5000 \text { cycles } \\
\text {-Compatibility }\end{array}$ & -Low chemical stability & & -Higher chemical stability \\
\hline & Economic & -Competitive cost & -High cost & & -Cheap solutions \\
\hline
\end{tabular}

Following the above selection criteria for most promising solutions on the road to ZEBs , technicians can ensure the optimum implementation of TES materials for improving the thermal performance and energy management of buildings. Moreover, the existing drawbacks pointed out for each material group should be addressed from design strategies to achieve a more effective integration. For instance, heat transfer rate of materials with low thermal conductivity can be enhanced by using composite materials (metal shavings or metal powder embedded in pure PCM) or by means of porous graphite matrixes or internal fins. Some critical issues highlighted above should be addressed in future R\&D efforts.

\section{Conclusions}

This paper reviews, from a critical perspective, recent advances on thermal energy storage materials and their applications towards zero energy buildings. Thermal energy storage in the form of sensible and latent heat has been identified as a very attractive strategy for high energy efficiency buildings. A careful assessment of available thermal energy storage materials leads to the following conclusions:

- Water and underground materials stand as the most convenient materials, due to their high sensible heat storage capacity and moderate thermal diffusivity. Water has a volumetric storage capacity of $250 \mathrm{MJ} / \mathrm{m}^{3}$ for heating purposes $\left(\Delta \mathrm{T}=60^{\circ} \mathrm{C}\right)$ and $63 \mathrm{MJ} / \mathrm{m}^{3}$ for cooling applications $\left(\Delta \mathrm{T}=15^{\circ} \mathrm{C}\right)$. Underground materials, such as rock or dry and wet soil, can store approximately $108 \mathrm{MJ} / \mathrm{m}^{3}\left(\Delta \mathrm{T}=50^{\circ} \mathrm{C}\right)$. In addition, underground solutions benefit from 
the insulation of soil, thus thermal energy is stored more efficiently as compared to above-ground solutions. Water and underground material applications in solar energy storage solutions and demand-side management strategies, yield an efficient reduction of energy consumption in buildings, leading to savings of over $30 \%$. Nevertheless, these materials require high storage volumes to meet annual heating demands. In addition, for long-term storage applications, underground thermal energy storage systems in large-scale solar energy plants are not yet competitive against fossil fuel systems, and only cover $3.2 \%$ of existing European district heating networks. Further research is required to cut back costs to enhance competitiveness, mainly in areas with high solar availability. In addition, new advances for heat loss reduction at short and long-term storage should be addressed through better construction and insulation techniques.

- Today, there are more than 250 commercially available organic and inorganic latent heat storage materials. Volumetric latent heat storage density of available organic and inorganic materials range from 100 up to $250 \mathrm{MJ} / \mathrm{m}^{3}$ and from 150 up to $430 \mathrm{MJ} / \mathrm{m}^{3}$, respectively. Phase change materials based on hydrated salts are considered as the best choice due to their high volumetric latent heat storage capacity, moderate thermal conductivity (approximately $0.6 \mathrm{~W} / \mathrm{m}^{\circ} \mathrm{C}$ ) and low-moderate cost. However, further considerations on long-term stability and reliability, as well as other issues that may affect safety and feasibility, should be carefully assessed. Their applications in free-cooling ventilation systems, solar energy storage solutions, and demand-side management strategies are promising on the road to zero energy buildings with a potential for non-renewable energy consumption reduction by up $90 \%$. However, PCM cost can represent more than $75 \%$ of the system cost, and charging/discharging periods, which affect the power capacity, are influenced by their low-moderate heat transfer rates. Further research is needed to reduce investment costs, increase heat transfer rates by improving thermal conductivity of materials (through new heat transfer enhancement techniques or new composite materials), and to demonstrate cost-optimal scenarios for their implementation. In addition, new advances to improve thermal reliability after a large number of thermal cycles (by more than 5000 for a lifespan of approximately 13-14 years) should be addressed.

- Regarding thermochemical energy storage materials, and in spite of the potentially high energy density achievable (up to $1510 \mathrm{MJ} / \mathrm{m}^{3}$ ) and long-term storage ability, there is no available material that satisfies all requirements for a viable deployment in building applications. The investment cost of most of the materials successfully tested at the laboratory scale ranges from 350 to $3600 € / \mathrm{m}^{3}$. In addition, thermochemical solutions require different tanks and heat exchangers that reduce the effective storage density, typically by more than $50 \%$ and increase final costs, which should be carefully addressed for small-scale applications. Additional research efforts must be pursued to optimise operation conditions, storage cycle efficiency, material cost and system designs.

\section{Acknowledgments}

This work was supported as part of the ClimACT project (SOE1/P3/P0429EU) within the Interreg Sudoe Programme, funded by European Regional Development Funds. The authors gratefully acknowledge the financial support of the Spanish Ministry of Education, Culture and Sport via a pre-doctoral contract granted to Francisco Jesús Lizana Moral (FPU14/06583); and the project "Hybrid thermochemical storage of concentrated solar power" supported by the Spanish Government Agency Ministerio de Economia y Competitividad and FEDER funds (Contract CTQ2014-52763-C2-2-R). 
Appendix A. Properties of commercially available PCMs from main existing companies

Table A1. Commercially available PCMs from Rubitherm [70].

\begin{tabular}{|c|c|c|c|c|c|c|c|c|c|}
\hline \multirow[b]{2}{*}{ Company } & \multirow[b]{2}{*}{ Type } & \multirow[b]{2}{*}{ Material } & \multicolumn{7}{|c|}{ Properties (solid/liquid) } \\
\hline & & & $\begin{array}{c}\text { Melting } \\
\text { temperature } \\
\left({ }^{\circ} \mathrm{C}\right)\end{array}$ & $\begin{array}{l}\text { Density } \\
\left(\mathrm{kg} / \mathrm{m}^{3}\right)\end{array}$ & $\begin{array}{c}\text { Thermal } \\
\text { conductivity } \\
\left(\mathrm{W} / \mathrm{m}^{\circ} \mathrm{C}\right)\end{array}$ & $\begin{array}{c}\text { Specific heat } \\
\text { capacity } \\
(\mathrm{kJ} / \mathrm{kgK})\end{array}$ & $\begin{array}{l}\text { Volumetric } \\
\text { heat } \\
\text { capacity } \\
\left(\mathrm{kJ} / \mathrm{m}^{3} \mathrm{~K}\right)\end{array}$ & $\begin{array}{l}\text { Latent } \\
\text { heat of } \\
\text { fusion } \\
(\mathrm{kJ} / \mathrm{kg})\end{array}$ & $\begin{array}{c}\text { Volumetric } \\
\text { latent heat } \\
\text { capacity } \\
\left(\mathrm{MJ} / \mathrm{m}^{3}\right)\end{array}$ \\
\hline Rubitherm & Organic PCMs & RT-9 HC & -9 & $880 / 770$ & 0.2 & 2 & 1760 & 250 & 220 \\
\hline Rubitherm & Organic PCMs & RT-4 & -4 & $880 / 760$ & 0.2 & 2 & 1760 & 180 & 158 \\
\hline Rubitherm & Organic PCMs & RTO & 0 & $880 / 770$ & 0.2 & 2 & 1760 & 175 & 154 \\
\hline Rubitherm & Organic PCMs & RT2 HC & 2 & $880 / 770$ & 0.2 & 2 & 1760 & 200 & 176 \\
\hline Rubitherm & Organic PCMs & RT3 HC_1 & 3 & $880 / 770$ & 0.2 & 2 & 1760 & 190 & 167 \\
\hline Rubitherm & Organic PCMs & RT4 & 4 & $880 / 770$ & 0.2 & 2 & 1760 & 175 & 154 \\
\hline Rubitherm & Organic PCMs & RT5 & 5 & $880 / 770$ & 0.2 & 2 & 1760 & 180 & 158 \\
\hline Rubitherm & Organic PCMs & RT5 HC & 5 & $880 / 760$ & 0.2 & 2 & 1760 & 250 & 220 \\
\hline Rubitherm & Organic PCMs & RT8 & 8 & $880 / 770$ & 0.2 & 2 & 1760 & 175 & 154 \\
\hline Rubitherm & Organic PCMs & RT8 HC & 8 & $880 / 770$ & 0.2 & 2 & 1760 & 190 & 167 \\
\hline Rubitherm & Organic PCMs & RT9 & 9 & $880 / 760$ & 0.2 & 2 & 1760 & 170 & 150 \\
\hline Rubitherm & Organic PCMs & RT10 & 10 & $880 / 770$ & 0.2 & 2 & 1760 & 160 & 141 \\
\hline Rubitherm & Organic PCMs & RT10 HC & 10 & $880 / 770$ & 0.2 & 2 & 1760 & 200 & 176 \\
\hline Rubitherm & Organic PCMs & RT11 HC & 11 & $880 / 770$ & 0.2 & 2 & 1760 & 200 & 176 \\
\hline Rubitherm & Organic PCMs & RT12 & 12 & $880 / 770$ & 0.2 & 2 & 1760 & 155 & 136 \\
\hline Rubitherm & Organic PCMs & RT15 & 15 & $880 / 770$ & 0.2 & 2 & 1760 & 155 & 136 \\
\hline Rubitherm & Organic PCMs & RT18 HC & 18 & $880 / 770$ & 0.2 & 2 & 1760 & 260 & 229 \\
\hline Rubitherm & Organic PCMs & RT21 & 21 & $880 / 770$ & 0.2 & 2 & 1760 & 155 & 136 \\
\hline Rubitherm & Organic PCMs & RT21 HC & 21 & $880 / 770$ & 0.2 & 2 & 1760 & 190 & 167 \\
\hline Rubitherm & Organic PCMs & RT22 HC & 22 & $760 / 700$ & 0.2 & 2 & 1520 & 190 & 144 \\
\hline Rubitherm & Organic PCMs & RT24 & 24 & $880 / 770$ & 0.2 & 2 & 1760 & 160 & 141 \\
\hline Rubitherm & Organic PCMs & RT25 & 25 & $880 / 760$ & 0.2 & 2 & 1760 & 170 & 150 \\
\hline Rubitherm & Organic PCMs & RT25 HC & 25 & $880 / 770$ & 0.2 & 2 & 1760 & 230 & 202 \\
\hline Rubitherm & Organic PCMs & RT26 & 26 & $880 / 750$ & 0.2 & 2 & 1760 & 180 & 158 \\
\hline Rubitherm & Organic PCMs & RT28 HC & 28 & $880 / 770$ & 0.2 & 2 & 1760 & 250 & 220 \\
\hline Rubitherm & Organic PCMs & RT31 & 31 & $880 / 760$ & 0.2 & 2 & 1760 & 165 & 145 \\
\hline Rubitherm & Organic PCMs & RT35 & 35 & $860 / 770$ & 0.2 & 2 & 1720 & 160 & 138 \\
\hline Rubitherm & Organic PCMs & RT42 & 42 & $880 / 760$ & 0.2 & 2 & 1760 & 165 & 145 \\
\hline Rubitherm & Organic PCMs & RT35 HC & 35 & $880 / 770$ & 0.2 & 2 & 1760 & 240 & 211 \\
\hline Rubitherm & Organic PCMs & RT44 HC & 44 & $800 / 700$ & 0.2 & 2 & 1600 & 250 & 200 \\
\hline Rubitherm & Organic PCMs & RT47 & 47 & $880 / 770$ & 0.2 & 2 & 1760 & 165 & 145 \\
\hline Rubitherm & Organic PCMs & RT50 & 50 & $880 / 760$ & 0.2 & 2 & 1760 & 160 & 141 \\
\hline Rubitherm & Organic PCMs & RT54 HC & 54 & $850 / 800$ & 0.2 & 2 & 1700 & 200 & 170 \\
\hline Rubitherm & Organic PCMs & RT55 & 55 & $880 / 770$ & 0.2 & 2 & 1760 & 170 & 150 \\
\hline Rubitherm & Organic PCMs & RT60 & 60 & $880 / 770$ & 0.2 & 2 & 1760 & 160 & 141 \\
\hline Rubitherm & Organic PCMs & RT64 HC & 64 & $880 / 780$ & 0.2 & 2 & 1760 & 250 & 220 \\
\hline Rubitherm & Organic PCMs & RT65 & 65 & $880 / 780$ & 0.2 & 2 & 1760 & 150 & 132 \\
\hline Rubitherm & Organic PCMs & RT69HC & 69 & $940 / 840$ & 0.2 & 2 & 1880 & 230 & 216 \\
\hline Rubitherm & Organic PCMs & RT70 HC & 70 & $880 / 770$ & 0.2 & 2 & 1760 & 260 & 229 \\
\hline Rubitherm & Organic PCMs & RT82 & 82 & $880 / 770$ & 0.2 & 2 & 1760 & 170 & 150 \\
\hline Rubitherm & Organic PCMs & RT80 HC & 80 & $900 / 800$ & 0.14 & 2 & 1800 & 220 & 198 \\
\hline Rubitherm & Organic PCMs & RT90 HC & 90 & $950 / 850$ & - & 2 & 1900 & 170 & 162 \\
\hline Rubitherm & Inorganic PCMs & SP-21 & -21 & $1300 / 1200$ & 0.6 & 2 & 2600 & 285 & 371 \\
\hline Rubitherm & Inorganic PCMs & SP-13 & -13 & $1250 / 1150$ & 0.6 & 2 & 2500 & 300 & 375 \\
\hline Rubitherm & Inorganic PCMs & SP-7_2 & -7 & $1300 / 1200$ & 0.6 & 2 & 2600 & 290 & 377 \\
\hline Rubitherm & Inorganic PCMs & SP5 & 5 & $1350 / 1400$ & 0.2 & 2 & 2700 & 170 & 230 \\
\hline Rubitherm & Inorganic PCMs & SP21 E & 21 & $1500 / 1400$ & 0.6 & 2 & 3000 & 170 & 255 \\
\hline Rubitherm & Inorganic PCMs & SP24 E & 24 & $1500 / 1400$ & 0.6 & 2 & 3000 & 180 & 270 \\
\hline Rubitherm & Inorganic PCMs & SP25 E2 & 25 & $1500 / 1400$ & 0.6 & 2 & 3000 & 180 & 270 \\
\hline Rubitherm & Inorganic PCMs & SP26 E & 26 & $1500 / 1400$ & 0.6 & 2 & 3000 & 180 & 270 \\
\hline Rubitherm & Inorganic PCMs & SP29 Eu & 29 & $1550 / 1500$ & 0.6 & 2 & 3100 & 200 & 310 \\
\hline Rubitherm & Inorganic PCMs & SP31 & 31 & $1350 / 1300$ & - & 2 & 2700 & 210 & 284 \\
\hline Rubitherm & Inorganic PCMs & SP58 & 58 & $1400 / 1300$ & 0.6 & 2 & 2800 & 250 & 350 \\
\hline Rubitherm & Inorganic PCMs & SP70 & 70 & $1500 / 1300$ & 0.6 & 2 & 3000 & 150 & 225 \\
\hline Rubitherm & Inorganic PCMs & SP90 & 90 & $1650 / 1700$ & 0.6 & 2 & 3300 & 150 & 248 \\
\hline Rubitherm & Powder & PX15 & 15 & 650 & 0.2 & 2 & & 85 & 55 \\
\hline Rubitherm & Powder & PX25 & 25 & 650 & 0.1 & 2 & & 95 & 62 \\
\hline Rubitherm & Powder & PX52 & 52 & 650 & 0.2 & 2 & & 100 & 65 \\
\hline Rubitherm & Powder & PX82 & 82 & 690 & 0.1 & 1.6 & & 105 & 72 \\
\hline Rubitherm & Granules & GR42 & 42 & 800 & 0.2 & 2 & & 55 & 44 \\
\hline Rubitherm & Granules & GR82 & 82 & 800 & 0.2 & 2 & & 55 & 44 \\
\hline
\end{tabular}


Table A2. Commercially available PCMs from Climator [71].

\begin{tabular}{|c|c|c|c|c|c|c|c|c|c|}
\hline \multirow[b]{2}{*}{ Company } & \multirow[b]{2}{*}{ Type } & \multirow[b]{2}{*}{ Material } & \multicolumn{7}{|c|}{ Properties (solid/liquid) } \\
\hline & & & $\begin{array}{c}\text { Melting } \\
\text { temperatur } \\
\mathrm{e}\left({ }^{\circ} \mathrm{C}\right)\end{array}$ & $\begin{array}{l}\text { Density } \\
\left(\mathrm{kg} / \mathrm{m}^{3}\right)\end{array}$ & $\begin{array}{c}\text { Thermal } \\
\text { conductivity } \\
\left(\mathrm{W} / \mathrm{m}^{\circ} \mathrm{C}\right)\end{array}$ & $\begin{array}{l}\text { Specific heat } \\
\text { capacity* }^{*} \\
(\mathrm{~kJ} / \mathrm{kgK})\end{array}$ & $\begin{array}{c}\text { Volumetric } \\
\text { heat } \\
\text { capacity* } \\
\left(\mathrm{kJ} / \mathrm{m}^{3} \mathrm{~K}\right)\end{array}$ & $\begin{array}{l}\text { Latent } \\
\text { heat of } \\
\text { fusion } \\
(\mathrm{kJ} / \mathrm{kg})\end{array}$ & $\begin{array}{c}\text { Volumetric } \\
\text { latent heat } \\
\text { capacity } \\
\left(\mathrm{MJ} / \mathrm{m}^{3}\right)\end{array}$ \\
\hline Climator & Salt hydrates & ClimSel C-21 & -21 & 1100 & $1.45 / 0.33$ & & & 285 & 314 \\
\hline Climator & Salt hydrates & ClimSel C-18 & -18 & 1150 & $2.17 / 0.56$ & & & 288 & 331 \\
\hline Climator & Salt hydrates & ClimSel C7 & 7 & 1400 & $0.78 / 0.59$ & & & 123 & 172 \\
\hline Climator & Salt hydrates & ClimSel C10 & 10 & 1400 & $0.83 / 0.70$ & & & 116 & 162 \\
\hline Climator & Salt hydrates & ClimSel C21 & 21 & 1400 & $0.93 / 0.75$ & & & 134 & 188 \\
\hline Climator & Salt hydrates & ClimSel C24 & 24 & 1400 & $0.74 / 0.93$ & & & 140 & 196 \\
\hline Climator & Salt hydrates & ClimSel C28 & 28 & 1400 & $0.98 / 0.72$ & & & 170 & 238 \\
\hline Climator & Salt hydrates & ClimSel C32 & 32 & 1400 & $0.76 / 1.08$ & & & 160 & 224 \\
\hline Climator & Salt hydrates & ClimSel C48 & 48 & 1300 & $0.76 / 0.53$ & & & 180 & 234 \\
\hline Climator & Salt hydrates & ClimSel C58 & 58 & 1400 & $0.57 / 0.47$ & & & 260 & 364 \\
\hline Climator & Salt hydrates & ClimSel C70 & 70 & 1700 & $0.81 / 0.81$ & & & 144 & 245 \\
\hline
\end{tabular}

${ }^{*}$ Not provided

Table A3. Commercially available PCMs from Cristopia Energy Systems [72,73].

\begin{tabular}{|c|c|c|c|c|c|c|c|c|c|}
\hline \multirow[b]{2}{*}{ Company } & \multirow[b]{2}{*}{ Type } & \multirow[b]{2}{*}{ Material } & \multicolumn{7}{|c|}{ Properties (solid/liquid) } \\
\hline & & & $\begin{array}{l}\text { Melting } \\
\text { temperatur } \\
\mathrm{e}\left({ }^{\circ} \mathrm{C}\right)\end{array}$ & $\begin{array}{l}\text { Density } \\
\left(\mathrm{kg} / \mathrm{m}^{3}\right)\end{array}$ & $\begin{array}{l}\text { Thermal } \\
\text { conductivity } \\
\left(\mathrm{W} / \mathrm{m}^{\circ} \mathrm{C}\right)\end{array}$ & $\begin{array}{c}\text { Specific heat } \\
\text { capacity }^{*} \\
(\mathrm{~kJ} / \mathrm{kgK})\end{array}$ & $\begin{array}{l}\text { Volumetric } \\
\text { heat } \\
\text { capacity* } \\
\left(\mathrm{kJ} / \mathrm{m}^{3} \mathrm{~K}\right)\end{array}$ & $\begin{array}{l}\text { Latent } \\
\text { heat of } \\
\text { fusion } \\
(\mathrm{kJ} / \mathrm{kg})\end{array}$ & $\begin{array}{l}\text { Volumetric } \\
\text { latent heat } \\
\text { capacity } \\
\left(\mathrm{MJ} / \mathrm{m}^{3}\right)\end{array}$ \\
\hline Cristopia Energy Systems & - & IN.15 & -15.4 & 602 & & & & 277 & 167 \\
\hline Cristopia Energy Systems & - & IN.12 & -11.7 & 620 & & & & 277 & 172 \\
\hline Cristopia Energy Systems & - & IN.10 & -10.4 & 617 & & & & 291 & 180 \\
\hline Cristopia Energy Systems & - & IN.06 & -5.5 & 625 & & & & 257 & 161 \\
\hline Cristopia Energy Systems & - & IN.03 & -2.6 & 592 & & & & 294 & 174 \\
\hline Cristopia Energy Systems & - & IC.00 & 0 & 558 & & & & 312 & 174 \\
\hline Cristopia Energy Systems & - & AC.00 & 0 & 560 & & & & 311 & 174 \\
\hline Cristopia Energy Systems & - & AC.27 & 27 & 867 & & & & 185 & 160 \\
\hline
\end{tabular}

Table A4. Commercially available PCMs from PCM Energy [74].

\begin{tabular}{|c|c|c|c|c|c|c|c|c|c|}
\hline \multirow[b]{2}{*}{ Company } & \multirow[b]{2}{*}{ Type } & \multirow[b]{2}{*}{ Material } & \multicolumn{7}{|c|}{ Properties (solid/liquid) } \\
\hline & & & $\begin{array}{l}\text { Melting } \\
\text { temperature } \\
\left({ }^{\circ} \mathrm{C}\right)\end{array}$ & $\begin{array}{l}\text { Density } \\
\left(\mathrm{kg} / \mathrm{m}^{3}\right)\end{array}$ & $\begin{array}{l}\text { Thermal } \\
\text { conductivity } \\
\left(\mathrm{W} / \mathrm{m}^{\circ} \mathrm{C}\right)\end{array}$ & $\begin{array}{c}\text { Specific heat } \\
\text { capacity } \\
(\mathrm{kJ} / \mathrm{kgK})\end{array}$ & $\begin{array}{l}\text { Volumetri } \\
\text { cheat } \\
\text { capacity } \\
\left(\mathrm{kJ} / \mathrm{m}^{3} \mathrm{~K}\right)\end{array}$ & $\begin{array}{l}\text { Latent } \\
\text { heat of } \\
\text { fusion } \\
(\mathrm{kJ} / \mathrm{kg})\end{array}$ & $\begin{array}{c}\text { Volumetric } \\
\text { latent heat } \\
\text { capacity } \\
\left(\mathrm{MJ} / \mathrm{m}^{3}\right)\end{array}$ \\
\hline PCM Energy & Hydrated salts & Latest $^{\mathrm{TM}}-50$ & -50 & 1300 & & & & 325 & 423 \\
\hline PCM Energy & Hydrated salts & Latest ${ }^{\mathrm{TM}}-23$ & -23 & 1200 & & & & 330 & 396 \\
\hline PCM Energy & Hydrated salts & Latest $^{\mathrm{TM}}-16$ & -16 & 1020 & & & & 330 & 337 \\
\hline PCM Energy & Hydrated salts & Latest $^{\mathrm{TM}} 0$ & 0 & 1000 & & & & 335 & 335 \\
\hline PCM Energy & Hydrated salts & Latest $^{\mathrm{TM}} 4$ & 4 & 1400 & & & & 105 & 147 \\
\hline PCM Energy & Hydrated salts & Latest $^{\mathrm{TM}} 7$ & 7 & 1400 & & & & 135 & 189 \\
\hline PCM Energy & Hydrated salts & Latest ${ }^{\mathrm{TM}} 7$ & 7 & 1400 & & & & 300 & 420 \\
\hline PCM Energy & Hydrated salts & Latest ${ }^{\mathrm{TM}} 10$ & 10 & 1400 & & & & 170 & 238 \\
\hline PCM Energy & Hydrated salts & Latest ${ }^{\mathrm{TM}} 15$ & 15 & 1400 & & & & 175 & 245 \\
\hline PCM Energy & Hydrated salts & Latest' ${ }^{\mathrm{TM}} 18 \mathrm{~T}$ & 18 & 1500 & & & & 175 & 263 \\
\hline PCM Energy & Hydrated salts & Latest $^{\mathrm{TM}} 21 \mathrm{~T}$ & 21 & 1500 & & & & 175 & 263 \\
\hline PCM Energy & Hydrated salts & Latest' ${ }^{\mathrm{TM}} 24 \mathrm{~T}$ & 24 & 1500 & & & & 175 & 263 \\
\hline PCM Energy & Hydrated salts & Latest ${ }^{\mathrm{TM}} 27 \mathrm{~T}$ & 27 & 1500 & & & & 175 & 263 \\
\hline PCM Energy & Hydrated salts & Latest' ${ }^{\mathrm{TM}} 29 \mathrm{~T}$ & 29 & 1500 & & & & 175 & 263 \\
\hline PCM Energy & Hydrated salts & Latest $^{\mathrm{TM}} 32 \mathrm{~S}$ & 32 & 1400 & & & & 210 & 294 \\
\hline PCM Energy & Hydrated salts & Latest $^{\mathrm{TM}} 36 \mathrm{~S}$ & 36 & 1400 & & & & 260 & 364 \\
\hline PCM Energy & Hydrated salts & Latest $^{\mathrm{TM}} 40 \mathrm{~S}$ & 40 & 1400 & & & & 220 & 308 \\
\hline PCM Energy & Hydrated salts & Latest $^{\mathrm{TM}} 45 \mathrm{~S}$ & 45 & 1400 & & & & 220 & 308 \\
\hline PCM Energy & Hydrated salts & Latest $^{\mathrm{TM}} 48 \mathrm{~S}$ & 48 & 1400 & & & & 220 & 308 \\
\hline PCM Energy & Hydrated salts & Latest $^{\mathrm{TM}} 58$ & 58 & 1400 & & & & 220 & 308 \\
\hline PCM Energy & Hydrated salts & Latest ${ }^{\mathrm{TM}} 68$ & 68 & 1800 & & & & 220 & 396 \\
\hline PCM Energy & Hydrated salts & Latest ${ }^{\mathrm{TM}} 70$ & 70 & 1800 & & & & 230 & 414 \\
\hline PCM Energy & Hydrated salts & Latest ${ }^{\mathrm{TM}} 78$ & 78 & 1800 & & & & 240 & 432 \\
\hline PCM Energy & Hydrated salts & Latest $^{\mathrm{TM}} 89$ & 89 & $1500 / 1600$ & & & & 145 & 218 \\
\hline
\end{tabular}


Table A5. Commercially available PCMs from PCM Products Ltd [75].

\begin{tabular}{|c|c|c|c|c|c|c|c|c|c|}
\hline \multirow[b]{2}{*}{ Company } & \multirow[b]{2}{*}{ Type } & \multirow[b]{2}{*}{ Material } & \multicolumn{7}{|c|}{ Properties (solid/liquid) } \\
\hline & & & $\begin{array}{c}\text { Melting } \\
\text { temperatur } \\
\mathrm{e}\left({ }^{\circ} \mathrm{C}\right)\end{array}$ & $\begin{array}{l}\text { Density } \\
\left(\mathrm{kg} / \mathrm{m}^{3}\right)\end{array}$ & $\begin{array}{l}\text { Thermal } \\
\text { conductivity } \\
\left(\mathrm{W} / \mathrm{m}^{\circ} \mathrm{C}\right)\end{array}$ & $\begin{array}{l}\text { Specific heat } \\
\text { capacity } \\
(\mathrm{kJ} / \mathrm{kgK})\end{array}$ & $\begin{array}{c}\text { Volumetric } \\
\text { heat } \\
\text { capacity } \\
\left(\mathrm{kJ} / \mathrm{m}^{3} \mathrm{~K}\right)\end{array}$ & $\begin{array}{l}\text { Latent } \\
\text { heat of } \\
\text { fusion } \\
(\mathrm{kJ} / \mathrm{kg})\end{array}$ & $\begin{array}{c}\text { Volumetric } \\
\text { latent heat } \\
\text { capacity } \\
\left(\mathrm{MJ} / \mathrm{m}^{3}\right) \\
\end{array}$ \\
\hline PCM Products & Eutectic PCMs & E0 & 0 & 1000 & 0.58 & 4.186 & 4186 & 332 & 332 \\
\hline PCM Products & Eutectic PCMs & $E-2$ & -2 & 1070 & 0.58 & 3.8 & 4066 & 306 & 327 \\
\hline PCM Products & Eutectic PCMs & E-3 & -3.7 & 1060 & 0.6 & 3.84 & 4070 & 312 & 331 \\
\hline PCM Products & Eutectic PCMs & E-6 & -6 & 1110 & 0.56 & 3.83 & 4251 & 275 & 305 \\
\hline PCM Products & Eutectic PCMs & $E-10$ & -10 & 1140 & 0.56 & 3.33 & 3796 & 286 & 326 \\
\hline PCM Products & Eutectic PCMs & $E-11$ & -11.6 & 1090 & 0.57 & 3.55 & 3870 & 301 & 328 \\
\hline PCM Products & Eutectic PCMs & $\mathrm{E}-12$ & -12.3 & 1110 & 0.56 & 3.47 & 3852 & 250 & 278 \\
\hline PCM Products & Eutectic PCMs & E-14 & -14.8 & 1220 & 0.53 & 3.51 & 4282 & 243 & 296 \\
\hline PCM Products & Eutectic PCMs & E-15 & -15 & 1060 & 0.53 & 3.87 & 4102 & 303 & 321 \\
\hline PCM Products & Eutectic PCMs & $E-19$ & -18.7 & 1125 & 0.58 & 3.29 & 3701 & 282 & 317 \\
\hline PCM Products & Eutectic PCMs & $\mathrm{E}-21$ & -20.6 & 1240 & 0.51 & 3.13 & 3881 & 263 & 326 \\
\hline PCM Products & Eutectic PCMs & E-22 & -22 & 1180 & 0.57 & 3.34 & 3941 & 234 & 276 \\
\hline PCM Products & Eutectic PCMs & E-26 & -26 & 1250 & 0.58 & 3.67 & 4588 & 260 & 325 \\
\hline PCM Products & Eutectic PCMs & E-29 & -29 & 1420 & 0.64 & 3.69 & 5240 & 222 & 315 \\
\hline PCM Products & Eutectic PCMs & E-32 & -32 & 1290 & 0.56 & 2.95 & 3806 & 243 & 313 \\
\hline PCM Products & Eutectic PCMs & E-34 & -33.6 & 1205 & 0.54 & 3.05 & 3675 & 240 & 289 \\
\hline PCM Products & Eutectic PCMs & E-37 & -36.5 & 1500 & 0.54 & 3.15 & 4725 & 213 & 320 \\
\hline PCM Products & Eutectic PCMs & E-50 & -49.8 & 1325 & 0.56 & 3.28 & 4346 & 218 & 289 \\
\hline PCM Products & Eutectic PCMs & E-75 & -75 & 902 & 0.17 & 2.43 & 2192 & 102 & 92 \\
\hline PCM Products & Eutectic PCMs & E-78 & -78 & 880 & 0.14 & 1.96 & 1725 & 115 & 101 \\
\hline PCM Products & Eutectic PCMs & E-90 & -90 & 786 & 0.14 & 2.56 & 2012 & 90 & 71 \\
\hline PCM Products & Eutectic PCMs & E-114 & -114 & 782 & 0.17 & 2.39 & 1869 & 107 & 84 \\
\hline PCM Products & Hydrated salts & S117 & 117 & 1450 & 0.7 & 2.61 & 3785 & 160 & 232 \\
\hline PCM Products & Hydrated salts & S89 & 89 & 1550 & 0.67 & 2.48 & 3844 & 151 & 234 \\
\hline PCM Products & Hydrated salts & S83 & 83 & 1600 & 0.62 & 2.31 & 3696 & 141 & 226 \\
\hline PCM Products & Hydrated salts & S72 & 72 & 1666 & 0.58 & 2.13 & 3549 & 127 & 212 \\
\hline PCM Products & Hydrated salts & S70 & 70 & 1680 & 0.57 & 2.1 & 3528 & 110 & 185 \\
\hline PCM Products & Hydrated salts & S58 & 58 & 1505 & 0.69 & 2.55 & 3838 & 145 & 218 \\
\hline PCM Products & Hydrated salts & S50 & 50 & 1601 & 0.43 & 1.59 & 2546 & 100 & 160 \\
\hline PCM Products & Hydrated salts & S46 & 46 & 1587 & 0.45 & 2.41 & 3825 & 210 & 333 \\
\hline PCM Products & Hydrated salts & S44 & 44 & 1584 & 0.43 & 1.61 & 2550 & 100 & 158 \\
\hline PCM Products & Hydrated salts & S34 & 34 & 2100 & 0.52 & 2.1 & 4410 & 115 & 242 \\
\hline PCM Products & Hydrated salts & S32 & 32 & 1460 & 0.51 & 1.91 & 2789 & 200 & 292 \\
\hline PCM Products & Hydrated salts & $\mathrm{S} 30$ & 30 & 1304 & 0.48 & 1.9 & 2478 & 190 & 248 \\
\hline PCM Products & Hydrated salts & S27 & 27 & 1530 & 0.54 & 2.2 & 3366 & 183 & 280 \\
\hline PCM Products & Hydrated salts & $\mathrm{S} 25$ & 25 & 1530 & 0.54 & 2.2 & 3366 & 180 & 275 \\
\hline PCM Products & Hydrated salts & S23 & 23 & 1530 & 0.54 & 2.2 & 3366 & 175 & 268 \\
\hline PCM Products & Hydrated salts & S21 & 22 & 1530 & 0.54 & 2.2 & 3366 & 170 & 260 \\
\hline PCM Products & Hydrated salts & S19 & 19 & 1520 & 0.43 & 1.9 & 2888 & 160 & 243 \\
\hline PCM Products & Hydrated salts & $\mathrm{S} 17$ & 17 & 1525 & 0.43 & 1.9 & 2898 & 160 & 244 \\
\hline PCM Products & Hydrated salts & S15 & 15 & 1510 & 0.43 & 1.9 & 2869 & 160 & 242 \\
\hline PCM Products & Hydrated salts & S13 & 13 & 1515 & 0.43 & 1.9 & 2879 & 160 & 242 \\
\hline PCM Products & Hydrated salts & $\mathrm{S} 10$ & 10 & 1470 & 0.43 & 1.9 & 2793 & 155 & 228 \\
\hline PCM Products & Hydrated salts & S8 & 8 & 1475 & 0.44 & 1.9 & 2803 & 150 & 221 \\
\hline PCM Products & Hydrated salts & S7 & 7 & 1700 & 0.4 & 1.85 & 3145 & 150 & 255 \\
\hline PCM Products & Organic PCMs & $\mathrm{A} 164^{*}$ & 164 & 1500 & - & 2.42 & 3630 & 290 & 435 \\
\hline PCM Products & Organic PCMs & A155 & 155 & 900 & 0.23 & 2.2 & 1980 & 100 & 90 \\
\hline PCM Products & Organic PCMs & A144 & 144 & 880 & 0.23 & 2.2 & 1936 & 115 & 101 \\
\hline PCM Products & Organic PCMs & A133 & 133 & 880 & 0.23 & 2.2 & 1936 & 126 & 111 \\
\hline PCM Products & Organic PCMs & $\mathrm{A} 118^{\star *}$ & 118 & 1450 & - & 2.7 & 3915 & 340 & 493 \\
\hline PCM Products & Organic PCMs & A95 & 95 & 900 & 0.22 & 2.2 & 1980 & 205 & 185 \\
\hline PCM Products & Organic PCMs & A82 & 82 & 850 & 0.22 & 2.21 & 1879 & 155 & 132 \\
\hline PCM Products & Organic PCMs & A70 & 70 & 890 & 0.23 & 2.2 & 1958 & 173 & 154 \\
\hline PCM Products & Organic PCMs & A62 & 62 & 910 & 0.22 & 2.2 & 2002 & 145 & 132 \\
\hline PCM Products & Organic PCMs & $\mathrm{A} 60 \mathrm{H}$ & 60 & 800 & 0.18 & 2.15 & 1720 & 212 & 170 \\
\hline PCM Products & Organic PCMs & A60 & 60 & 910 & 0.22 & 2.22 & 2020 & 145 & 132 \\
\hline PCM Products & Organic PCMs & $\mathrm{A} 58 \mathrm{H}$ & 58 & 820 & 0.18 & 2.85 & 2337 & 243 & 199 \\
\hline PCM Products & Organic PCMs & A58 & 58 & 910 & 0.22 & 2.22 & 2020 & 132 & 120 \\
\hline PCM Products & Organic PCMs & A55 & 55 & 905 & 0.22 & 2.22 & 2009 & 135 & 122 \\
\hline PCM Products & Organic PCMs & $\mathrm{A} 53 \mathrm{H}$ & 53 & 810 & 0.18 & 2.02 & 1636 & 166 & 134 \\
\hline PCM Products & Organic PCMs & A53 & 53 & 910 & 0.22 & 2.22 & 2020 & 130 & 118 \\
\hline PCM Products & Organic PCMs & A52 & 52 & 810 & 0.18 & 2.15 & 1742 & 222 & 180 \\
\hline PCM Products & Organic PCMs & $\mathrm{A} 50$ & 50 & 810 & 0.18 & 2.15 & 1742 & 218 & 177 \\
\hline PCM Products & Organic PCMs & A48 & 48 & 810 & 0.18 & 2.85 & 2309 & 234 & 190 \\
\hline PCM Products & Organic PCMs & A46 & 46 & 910 & 0.22 & 2.22 & 2020 & 155 & 141 \\
\hline
\end{tabular}




\begin{tabular}{|c|c|c|c|c|c|c|c|c|c|}
\hline PCM Products & Organic PCMs & A44 & 44 & 805 & 0.18 & 2.15 & 1731 & 242 & 195 \\
\hline PCM Products & Organic PCMs & A43 & 43 & 780 & 0.18 & 2.37 & 1849 & 165 & 129 \\
\hline PCM Products & Organic PCMs & A42 & 42 & 905 & 0.21 & 2.22 & 2009 & 105 & 95 \\
\hline PCM Products & Organic PCMs & A40 & 40 & 810 & 0.18 & 2.43 & 1968 & 230 & 186 \\
\hline PCM Products & Organic PCMs & A39 & 39 & 900 & 0.22 & 2.22 & 1998 & 105 & 95 \\
\hline PCM Products & Organic PCMs & A37 & 37 & 810 & 0.18 & 2.85 & 2309 & 235 & 190 \\
\hline PCM Products & Organic PCMs & A36 & 36 & 790 & 0.18 & 2.37 & 1872 & 217 & 171 \\
\hline PCM Products & Organic PCMs & A32 & 32 & 845 & 0.21 & 2.2 & 1859 & 130 & 110 \\
\hline PCM Products & Organic PCMs & A29 & 29 & 810 & 0.18 & 2.15 & 1742 & 226 & 183 \\
\hline PCM Products & Organic PCMs & A28 & 28 & 789 & 0.21 & 2.22 & 1752 & 155 & 122 \\
\hline PCM Products & Organic PCMs & A26 & 26 & 790 & 0.21 & 2.22 & 1754 & 150 & 119 \\
\hline PCM Products & Organic PCMs & $\mathrm{A} 25 \mathrm{H}$ & 25 & 810 & 0.18 & 2.15 & 1742 & 226 & 183 \\
\hline PCM Products & Organic PCMs & A25 & 25 & 785 & 0.18 & 2.26 & 1774 & 150 & 118 \\
\hline PCM Products & Organic PCMs & A24 & 24 & 790 & 0.18 & 2.22 & 1754 & 145 & 115 \\
\hline PCM Products & Organic PCMs & A23 & 23 & 785 & 0.18 & 2.22 & 1743 & 145 & 114 \\
\hline PCM Products & Organic PCMs & $\mathrm{A} 22 \mathrm{H}$ & 22 & 820 & 0.18 & 2.85 & 2337 & 216 & 177 \\
\hline PCM Products & Organic PCMs & A22 & 22 & 785 & 0.18 & 2.22 & 1743 & 145 & 114 \\
\hline PCM Products & Organic PCMs & A17 & 17 & 785 & 0.18 & 2.22 & 1743 & 150 & 118 \\
\hline PCM Products & Organic PCMs & A16 & 16 & 760 & 0.18 & 2.37 & 1801 & 213 & 162 \\
\hline PCM Products & Organic PCMs & A15 & 15 & 790 & 0.18 & 2.26 & 1785 & 130 & 103 \\
\hline PCM Products & Organic PCMs & A9 & 9 & 775 & 0.21 & 2.16 & 1674 & 140 & 109 \\
\hline PCM Products & Organic PCMs & A8 & 8 & 773 & 0.21 & 2.16 & 1670 & 150 & 116 \\
\hline PCM Products & Organic PCMs & $\mathrm{A} 6$ & 6 & 770 & 0.21 & 2.17 & 1671 & 150 & 116 \\
\hline PCM Products & Organic PCMs & A4 & 4 & 766 & 0.21 & 2.18 & 1670 & 200 & 153 \\
\hline PCM Products & Organic PCMs & A3 & 3 & 765 & 0.21 & 2.2 & 1683 & 200 & 153 \\
\hline PCM Products & Organic PCMs & $\mathrm{A} 2$ & 2 & 765 & 0.21 & 2.2 & 1683 & 200 & 153 \\
\hline PCM Products & Solid-solid & $\mathrm{X} 25$ & 25 & 1055 & 0.36 & 1.63 & 1720 & 110 & 116 \\
\hline PCM Products & Solid-solid & X30 & 30 & 1050 & 0.36 & 1.65 & 1733 & 105 & 110 \\
\hline PCM Products & Solid-solid & $\mathrm{X} 40$ & 40 & 1046 & 0.36 & 1.67 & 1747 & 125 & 131 \\
\hline PCM Products & Solid-solid & $\mathrm{X55}$ & 55 & 1060 & 0.36 & 1.62 & 1717 & 115 & 122 \\
\hline PCM Products & Solid-solid & $\mathrm{X} 70$ & 70 & 1085 & 0.36 & 1.57 & 1703 & 125 & 136 \\
\hline PCM Products & Solid-solid & $\mathrm{X} 80$ & 80 & 1193 & 0.36 & 1.52 & 1813 & 140 & 167 \\
\hline PCM Products & Solid-solid & X90 & 90 & 1200 & 0.36 & 1.51 & 1812 & 135 & 162 \\
\hline PCM Products & Solid-solid & X95 & 95 & 1215 & 0.36 & 1.51 & 1835 & 140 & 170 \\
\hline PCM Products & Solid-solid & $\mathrm{X} 120$ & 120 & 1245 & 0.36 & 1.5 & 1868 & 180 & 224 \\
\hline PCM Products & Solid-solid & $\mathrm{X} 130$ & 130 & 1280 & 0.36 & 1.47 & 1882 & 260 & 333 \\
\hline PCM Products & Solid-solid & $\mathrm{X} 165$ & 165 & 1304 & 0.36 & 1.43 & 1865 & 230 & 300 \\
\hline PCM Products & Solid-solid & $\mathrm{X} 180$ & 180 & 1330 & 0.36 & 1.4 & 1862 & 280 & 372 \\
\hline
\end{tabular}

Table A6. Commercially available PCMs from BASF (Micronal PCM) [76].

\begin{tabular}{|c|c|c|c|c|c|c|c|c|c|}
\hline \multirow[b]{2}{*}{ Company } & \multirow[b]{2}{*}{ Type } & \multirow[b]{2}{*}{ Material } & \multicolumn{7}{|c|}{ Properties (solid/liquid) } \\
\hline & & & $\begin{array}{c}\text { Melting } \\
\text { temperatur } \\
\mathrm{e}\left({ }^{\circ} \mathrm{C}\right)\end{array}$ & $\begin{array}{l}\text { Density } \\
\left(\mathrm{kg} / \mathrm{m}^{3}\right)\end{array}$ & $\begin{array}{l}\text { Thermal } \\
\text { conductivity } \\
\left(\mathrm{W} / \mathrm{m}^{\circ} \mathrm{C}\right)\end{array}$ & $\begin{array}{l}\text { Specific heat } \\
\text { capacity* } \\
(\mathrm{kJ} / \mathrm{kgK})\end{array}$ & $\begin{array}{c}\text { Volumetric } \\
\text { heat } \\
\text { capacity* } \\
\left(\mathrm{kJ} / \mathrm{m}^{3} \mathrm{~K}\right)\end{array}$ & $\begin{array}{l}\text { Latent } \\
\text { heat of } \\
\text { fusion } \\
(\mathrm{kJ} / \mathrm{kg})\end{array}$ & $\begin{array}{c}\text { Volumetric } \\
\text { latent heat } \\
\text { capacity } \\
\left(\mathrm{MJ} / \mathrm{m}^{3}\right)\end{array}$ \\
\hline BASF - Micronal PCM & Dispersion & DS 5000 & 26 & - & & & & 45 & \\
\hline BASF - Micronal PCM & Dispersion & DS 5007 & 23 & - & & & & 41 & \\
\hline BASF - Micronal PCM & Dispersion & DS 5030 & 21 & - & & & & 37 & \\
\hline BASF - Micronal PCM & Pulver & DS 5001 & 26 & $250-350$ & & & & 110 & 33 \\
\hline BASF - Micronal PCM & Pulver & DS 5008 & 23 & $250-350$ & & & & 100 & 30 \\
\hline BASF - Micronal PCM & Pulver & DS 5029 & 21 & $250-350$ & & & & 90 & 27 \\
\hline
\end{tabular}

Table A7. Commercially available PCMs from RGees. savENRG ${ }^{\mathrm{TM}}$ [77].

\begin{tabular}{|c|c|c|c|c|c|c|c|c|c|}
\hline \multirow[b]{2}{*}{ Company } & \multirow[b]{2}{*}{ Type } & \multirow[b]{2}{*}{ Material } & \multicolumn{7}{|c|}{ Properties (solid/liquid) } \\
\hline & & & $\begin{array}{c}\text { Melting } \\
\text { temperatur } \\
\mathrm{e}\left({ }^{\circ} \mathrm{C}\right)\end{array}$ & $\begin{array}{l}\text { Density } \\
\left(\mathrm{kg} / \mathrm{m}^{3}\right)\end{array}$ & $\begin{array}{c}\text { Thermal } \\
\text { conductivity* } \\
\left(\mathrm{W} / \mathrm{m}^{\circ} \mathrm{C}\right)\end{array}$ & $\begin{array}{l}\text { Specific heat } \\
\text { capacity* } \\
(\mathrm{kJ} / \mathrm{kgK})\end{array}$ & $\begin{array}{c}\text { Volumetric } \\
\text { heat } \\
\text { capacity } \\
\left(\mathrm{kJ} / \mathrm{m}^{3} \mathrm{~K}\right)\end{array}$ & $\begin{array}{l}\text { Latent } \\
\text { heat of } \\
\text { fusion } \\
(\mathrm{kJ} / \mathrm{kg})\end{array}$ & $\begin{array}{c}\text { Volumetric } \\
\text { latent heat } \\
\text { capacity } \\
\left(\mathrm{MJ} / \mathrm{m}^{3}\right) \\
\end{array}$ \\
\hline Rgees & Hydrated salts & PCM-HS26N & -26 & 1200 & & & & 205 & 246 \\
\hline Rgees & Hydrated salts & PCM-HS23N & -23 & 1180 & & & & 200 & 236 \\
\hline Rgees & Hydrated salts & PCM-HS10N & -10 & 1100 & & & & 220 & 242 \\
\hline Rgees & Hydrated salts & PCM-HS22P & 22 & 1540 & & & & 185 & 285 \\
\hline Rgees & Organic PCMs & PCM-OM06P & 5.5 & 735 & & & & 260 & 191 \\
\hline Rgees & Organic PCMs & PCM-OM18P & 18 & 735 & & & & 260 & 191 \\
\hline Rgees & Organic PCMs & PCM-OM37P & 37 & 880 & & & & 218 & 192 \\
\hline Rgees & Organic PCMs & PCM-OM65P & 65 & 840 & & & & 210 & 176 \\
\hline
\end{tabular}


Table A8. Commercially available PCMs from Entropy solutions (PureTemp) [69].

\begin{tabular}{|c|c|c|c|c|c|c|c|c|c|}
\hline \multirow[b]{2}{*}{ Company } & \multirow[b]{2}{*}{ Type } & \multirow[b]{2}{*}{ Material } & \multicolumn{7}{|c|}{ Properties (solid/liquid) } \\
\hline & & & $\begin{array}{c}\text { Melting } \\
\text { temperatur } \\
\mathrm{e}\left({ }^{\circ} \mathrm{C}\right)\end{array}$ & $\begin{array}{l}\text { Density } \\
\left(\mathrm{kg} / \mathrm{m}^{3}\right)\end{array}$ & $\begin{array}{c}\text { Thermal } \\
\text { conductivity* } \\
\left(\mathrm{W} / \mathrm{m}^{\circ} \mathrm{C}\right)\end{array}$ & $\begin{array}{l}\text { Specific heat } \\
\text { capacity* } \\
(\mathrm{kJ} / \mathrm{kgK})\end{array}$ & $\begin{array}{c}\text { Volumetric } \\
\text { heat } \\
\text { capacity } \\
\left(\mathrm{kJ} / \mathrm{m}^{3} \mathrm{~K}\right)\end{array}$ & $\begin{array}{l}\text { Latent } \\
\text { heat of } \\
\text { fusion } \\
(\mathrm{kJ} / \mathrm{kg})\end{array}$ & $\begin{array}{c}\text { Volumetric } \\
\text { latent heat } \\
\text { capacity } \\
\left(\mathrm{MJ} / \mathrm{m}^{3}\right)\end{array}$ \\
\hline PureTemp & Organic PCMs & PureTemp -37 & -37 & 880 & & & & 145 & 128 \\
\hline PureTemp & Organic PCMs & PureTemp -21 & -21 & 1060 & & & & 239 & 253 \\
\hline PureTemp & Organic PCMs & PureTemp -15 & -15 & 1030 & & & & 301 & 310 \\
\hline PureTemp & Organic PCMs & PureTemp -2 & -2 & 1020 & & & & 277 & 283 \\
\hline PureTemp & Organic PCMs & PureTemp 1 & 1 & 1000 & & & & 301 & 301 \\
\hline PureTemp & Organic PCMs & PureTemp 4 & 5 & 880 & & & & 187 & 165 \\
\hline PureTemp & Organic PCMs & PureTemp 6 & 6 & 760 & & & & 220 & 167 \\
\hline PureTemp & Organic PCMs & PureTemp 7 & 7 & 830 & & & & 185 & 154 \\
\hline PureTemp & Organic PCMs & PureTemp 8 & 8 & 860 & & & & 178 & 153 \\
\hline PureTemp & Organic PCMs & PureTemp 12 & 12 & 860 & & & & 181 & 156 \\
\hline PureTemp & Organic PCMs & PureTemp 15 & 15 & 860 & & & & 182 & 157 \\
\hline PureTemp & Organic PCMs & PureTemp 18 & 18 & 860 & & & & 192 & 165 \\
\hline PureTemp & Organic PCMs & PureTemp 20 & 20 & 860 & & & & 171 & 147 \\
\hline PureTemp & Organic PCMs & PureTemp 23 & 23 & 830 & & & & 227 & 188 \\
\hline PureTemp & Organic PCMs & PureTemp 25 & 25 & 860 & & & & 187 & 161 \\
\hline PureTemp & Organic PCMs & PureTemp 27 & 27 & 860 & & & & 202 & 174 \\
\hline PureTemp & Organic PCMs & PureTemp 28 & 28 & 860 & & & & 190 & 163 \\
\hline PureTemp & Organic PCMs & PureTemp 29 & 29 & 850 & & & & 202 & 172 \\
\hline PureTemp & Organic PCMs & PureTemp 37 & 38 & 840 & & & & 210 & 176 \\
\hline PureTemp & Organic PCMs & PureTemp 42 & 42 & 850 & & & & 218 & 185 \\
\hline PureTemp & Organic PCMs & PureTemp 48 & 48 & 820 & & & & 230 & 189 \\
\hline PureTemp & Organic PCMs & PureTemp 53 & 53 & 840 & & & & 225 & 189 \\
\hline PureTemp & Organic PCMs & PureTemp 58 & 58 & 810 & & & & 225 & 182 \\
\hline PureTemp & Organic PCMs & PureTemp 60 & 61 & 870 & & & & 220 & 191 \\
\hline PureTemp & Organic PCMs & PureTemp 63 & 63 & 840 & & & & 206 & 173 \\
\hline PureTemp & Organic PCMs & PureTemp 68 & 68 & 870 & & & & 213 & 185 \\
\hline PureTemp & Organic PCMs & PureTemp 108 & 108 & 800 & & & & 180 & 144 \\
\hline PureTemp & Organic PCMs & PureTemp 151 & 151 & 1360 & & & & 217 & 295 \\
\hline
\end{tabular}

${ }^{*}$ Not provided 


\section{References}

[1] International Energy Agency. Transition to Sustainable Buildings. Strategies and Opportunities to 2050. OECD/IEA; 2013. doi:10.1787/9789264202955-en.

[2] The European Parliament and the Council of the European Union. Directive 2010/31/EU of the European Parliament and of the Council of 19 May 2010 on the Energy Performance of Building (recast). Official Journal of the European Union; 2010.

[3] European Commission. An EU Strategy on Heating and Cooling (COM(2016) 51 final). 2016.

[4] Kalaiselvam S, Parameshwaran R. Thermal energy storage technologies for sustainability: systems design, assessment, and applications. 1st ed. Academic Press; 2014.

[5] Hyman L. Overview. Sustainable Thermal Storage Systems: Planning, Design, and Operations, The McGrawHill; 2011, p. 1-23.

[6] Tatsidjodoung P, Le Pierrès N, Luo L. A review of potential materials for thermal energy storage in building applications. Renewable and Sustainable Energy Reviews 2013;18:327-49. doi:10.1016/j.rser.2012.10.025.

[7] Navarro L, de Gracia A, Niall D, Castell A, Browne M, McCormack SJ, et al. Thermal energy storage in building integrated thermal systems: A review. Part 2. Integration as passive system. Renewable Energy 2015. doi:10.1016/..renene.2015.06.064.

[8] Navarro L, Gracia A De, Niall D, Castell A, Browne M, Mccormack SJ, et al. Thermal energy storage in building integrated thermal systems: A review. Part 1. Active storage systemsreadable. Renewable Energy 2016;88:52647. doi:http://dx.doi.org/10.1016/j.renene.2015.11.040.

[9] European Commission. Horizon 2020 Work Programme 2016-2017. European Union: 2016.

[10] International Energy Agency. R\&D programme on energy storage: Energy Conservation through Energy Storage (ECES IA) n.d. http://www.iea-eces.org/ (accessed January 24, 2016).

[11] Statoil. Energy Perspectives. Long-term macro and market outlook. 2013.

[12] Lizana J, Barrios-Padura Á, Molina-Huelva M, Chacartegui R. Multi-criteria assessment for the effective decision management in residential energy retrofitting. Energy \& Buildings 2016;129:284-307. doi:10.1016/j.enbuild.2016.07.043.

[13] W.AA. Guía del almacenamiento de energía. Madrid: Fundación de la Energía de la Comunidad de Madrid; 2011.

[14] Mehling H, Cabeza LF. Heat and cold storage with PCM. An up to date introduction into basics and applications. Springer; 2008.

[15] ISO 10456:2007. Building materials and products. Hygrothermal properties. Tabulated design values and procedures for determining declared and design thermal values. 2007.

[16] de Gracia A, Cabeza LF. Phase change materials and thermal energy storage for buildings. Energy and Buildings 2015;103:414-9. doi:10.1016/j.enbuild.2015.06.007.

[17] Yu N, Wang RZ, Wang LW. Sorption thermal storage for solar energy. Progress in Energy and Combustion Science 2013;39:489-514. doi:10.1016/j.pecs.2013.05.004 Review.

[18] N'Tsoukpoe KE, Liu H, Le Pierrès N, Luo L. A review on long-term sorption solar energy storage. Renewable and Sustainable Energy Reviews 2009;13:2385-96. doi:10.1016/j.rser.2009.05.008.

[19] Davidson JH, Quinnell J, Burch J, Zondag H a, Boer R De, Finck C, et al. Development of Space Heating and Domestic Hot Water Systems with Compact Thermal Energy Storage. Compact Thermal Energy Storage: Material Development for System Integration, Report of the IEA SHC/ECES programme - Task 42/Annex 24; 2013.

[20] Parameshwaran R, Kalaiselvam S, Harikrishnan S, Elayaperumal a. Sustainable thermal energy storage technologies for buildings: A review. Renewable and Sustainable Energy Reviews 2012;16:2394-433. doi:10.1016/j.rser.2012.01.058. 
[21] Heier J, Bales C, Martin V. Combining thermal energy storage with buildings - a review. Renewable and Sustainable Energy Reviews 2015;42:1305-25. doi:10.1016/j.rser.2014.11.031.

[22] Waqas A, Ud Din Z. Phase change material (PCM) storage for free cooling of buildings-A review. Renewable and Sustainable Energy Reviews 2013;18:607-25. doi:10.1016/j.rser.2012.10.034.

[23] Hasan A, McCormack SJ, Huang MJ, Norton B. Energy and cost saving of a photovoltaic-phase change materials (PV-PCM) System through temperature regulation and performance enhancement of photovoltaics. Energies 2014;7:1318-31. doi:10.3390/en7031318.

[24] Huang MJ, Eames PC, Norton B. Thermal regulation of building-integrated photovoltaics using phase change materials. International Journal of Heat and Mass Transfer 2004:47:2715-33. doi:10.1016/j.jijheatmasstransfer.2003.11.015.

[25] Huang MJ, Eames PC, Norton B. Phase change materials for limiting temperature rise in building integrated photovoltaics. Solar Energy 2006;80:1121-30. doi:10.1016/j.solener.2005.10.006.

[26] Kalaiselvam S, Parameshwaran R. Chapter 4: Sensible Thermal energy Storage. Thermal energy storage technologies for sustainability: systems design, assessment, and applications. 1st ed., Academic Press; 2014, p. 65-81.

[27] Ståhl F. Influence of thermal mass on the heating and cooling demands of a building unit. PhD thesis. Sweden: Chalmers University of Technology, 2009.

[28] Abhat A. Short term thermal energy storage. Revue de Physique Appliquée 1980;15:477-501. doi:10.1051/rphysap:01980001503047700.

[29] Sharma A, Tyagi W, Chen CR, Buddhi D. Review on thermal energy storage with phase change materials and applications. Renewable and Sustainable Energy Reviews 2009;13:318-45. doi:10.1016/j.rser.2007.10.005.

[30] Kalaiselvam S, Parameshwaran R. Chapter 3: Thermal Energy Storage Technologies. Thermal energy storage technologies for sustainability: systems design, assessment, and applications. 1st ed., Academic Press; 2014, p. 57-64.

[31] Tudela F. Ecodiseño. Universidad Autónoma Metropolitana de Xochimilco; 1982.

[32] Asan H, Sancaktar YS. Effects of wall's thermophysical properties on time lag and decrement factor. Energy and Buildings 1998;28:159-66. doi:10.1016/S0378-7788(98)00007-3.

[33] BEDEC. Instituto de Tecnología de la Construcción de Cataluña - ITeC n.d. http://itec.es/noubedec.e/bedec.aspx (accessed November 9, 2016).

[34] PREOC 2016. Precios de edificación y obra civil en España 2016.

[35] Generador de precios de la construcción. España. CYPE Ingenieros, S.A. n.d. http://www.generadordeprecios.info/ (accessed November 9, 2016).

[36] Ogoli DM. Predicting indoor temperatures in closed buildings with high thermal mass. Energy and Buildings 2003;35:851-62. doi:10.1016/S0378-7788(02)00246-3.

[37] Karlsson J, Wadsö L, Öberg M. A conceptual model that simulates the influence of thermal inertia in building structures. Energy and Buildings 2013;60:146-51. doi:10.1016/j.enbuild.2013.01.017.

[38] Rempel A, Rempel A. Rocks, Clays, Water, and Salts: Highly Durable, Infinitely Rechargeable, Eminently Controllable Thermal Batteries for Buildings. Geosciences 2013;3:63-101. doi:10.3390/geosciences3010063.

[39] Al-Sanea SA, Zedan MF, Al-Hussain SN. Effect of thermal mass on performance of insulated building walls and the concept of energy savings potential. Applied Energy 2012;89:430-42. doi:10.1016/j.apenergy.2011.08.009.

[40] Bloomfield DP, Fisk DJ. The optimisation of intermittent heating. Building and Environment 1977;12:43-55. doi:https://doi.org/10.1016/0360-1323(77)90006-3.

[41] Kim Y, Norford LK. Optimal use of thermal energy storage resources in commercial buildings through pricebased demand response considering distribution network operation. Applied Energy 2017;193:308-24. doi:10.1016/j.apenergy.2017.02.046. 
[42] Arteconi A, Hewitt NJ, Polonara F. Domestic demand-side management (DSM): Role of heat pumps and thermal energy storage (TES) systems. Applied Thermal Engineering 2013;51:155-65. doi:10.1016/j.applthermaleng.2012.09.023.

[43] Arteconi A, Hewitt NJ, Polonara F. State of the art of thermal storage for demand-side management. Applied Energy 2012;93:371-89. doi:10.1016/j.apenergy.2011.12.045.

[44] Renaldi R, Kiprakis A, Friedrich D. An optimisation framework for thermal energy storage integration in a residential heat pump heating system. Applied Energy 2015. doi:10.1016/j.apenergy.2016.02.067.

[45] Xu J, Wang RZ, Li Y. A review of available technologies for seasonal thermal energy storage. Solar Energy 2014;103:610-38. doi:10.1016/j.solener.2013.06.006.

[46] EINSTEIN Proyect (2012-2015). Effective Integration of Seasonal Thermal Energy Storage Systems in existing buildings. European Project 2015. ww.einstein-project.eu.

[47] Xu J, Li Y, Wang RZ, Liu W. Performance investigation of a solar heating system with underground seasonal energy storage for greenhouse application. Energy 2014;67:63-73. doi:10.1016/j.energy.2014.01.049.

[48] Sibbitt B, McClenahan D, Djebbar R, Thornton J, Wong B, Carriere J, et al. The performance of a high solar fraction seasonal storage district heating system - Five years of operation. Energy Procedia 2012;30:856-65. doi:10.1016/j.egypro.2012.11.097.

[49] International Energy Agency. Technology Roadmap. Energy-efficient Buildings: Heating and Cooling Equipment. France: OECD/IEA; 2011. doi:10.1007/SpringerReference_7300.

[50] Kalaiselvam S, Parameshwaran R. Chapter 7: Seasonal Thermal Energy Storage. Thermal energy storage technologies for sustainability: systems design, assessment, and applications. 1st ed., Academic Press; 2014, p. 145-62.

[51] Rapantova N, Pospisil P, Koziorek J, Vojcinak P, Grycz D, Rozehnal Z. Optimisation of experimental operation of borehole thermal energy storage. Applied Energy 2016;181:464-76. doi:10.1016/j.apenergy.2016.08.091.

[52] Large Scale Solar Heating Plants. Plant database n.d. http://solar-districtheating.eu/ServicesTools/Plantdatabase.aspx (accessed February 23, 2016).

[53] Gils HC, Cofala J, Wagner F, Schöpp W. GIS-based assessment of the district heating potential in the USA. Energy 2013;58:318-29. doi:10.1016/j.energy.2013.06.028.

[54] Nussbaumer T, Thalmann S. Influence of system design on heat distribution costs in district heating. Energy 2016;101:496-505. doi:10.1016/j.energy.2016.02.062.

[55] Lizana J, Ortiz C, Soltero VM, Chacartegui R. District heating systems based on low-carbon energy technologies in Mediterranean areas. Energy 2017;120:397-416. doi:10.1016/j.energy.2016.11.096.

[56] Abhat A. Low temperature latent heat thermal energy storage: Heat storage materials. Solar Energy 1983;30:313-32.

[57] Zhou D, Zhao CY, Tian Y. Review on thermal energy storage with phase change materials (PCMs) in building applications. Applied Energy 2012;92:593-605. doi:10.1016/j.apenergy.2011.08.025.

[58] Kalnæs SE, Jelle BP. Phase change materials and products for building applications: A state-of-the-art review and future research opportunities. Energy and Buildings 2015;94:150-76. doi:10.1016/j.enbuild.2015.02.023.

[59] Mehling H, Cabeza LF. Phase change materials and their basic properties. Thermal Energy Storage for Sustainable Energy Consumption, vol. 234, 2007, p. 257-77. doi:10.1007/978-1-4020-5290-3_17.

[60] Oliver A, Neila FJ, García-Santos A. PCM choosing and classification according to their characteristics for their application for thermal energy storage systems. Materiales de Construcción 2012;62:131-40. doi:10.3989/mc.2012.58010.

[61] Harikrishnan S, Deenadhayalan M, Kalaiselvam S. Experimental investigation of solidification and melting characteristics of composite PCMs for building heating application. Energy Conversion and Management 2014;86:864-72. doi:10.1016/j.enconman.2014.06.042. 
[62] Hasnain S.M. Latent heat thermal energy storage for solar heating applications. University of Leeds, 1990.

[63] Hasnain S.M. Review on sustainable thermal energy storage technologies, Part I: heat storage materials and techniques. Energy Conversion and Management 1998;39:1127-38. doi:10.1016/S0196-8904(98)00025-9.

[64] Lv P, Liu C, Rao Z. Experiment study on the thermal properties of paraffin/kaolin thermal energy storage formstable phase change materials. Applied Energy 2016;182:475-87. doi:10.1016/j.apenergy.2016.08.147.

[65] Pereira da Cunha J, Eames P. Thermal energy storage for low and medium temperature applications using phase change materials - A review. Applied Energy 2016;177:227-38. doi:10.1016/j.apenergy.2016.05.097.

[66] Mehling H, Cabeza LF. Solid-liquid phase change materials. Heat and cold storage with PCM An up to date introduction into basics and applications, Springer; 2008, p. 11-55.

[67] Campos-Celador Á, Diarce G, Zubiaga JT, Bandos T V., García-Romero AM, López LM, et al. Design of a finned plate latent heat thermal energy storage system for domestic applications. Energy Procedia 2014;48:300-8. doi:10.1016/j.egypro.2014.02.035.

[68] Rezaei M, Anisur MR, Mahfuz MH, Kibria MA, Saidur R, Metselaar IHSC. Performance and cost analysis of phase change materials with different melting temperatures in heating systems. Energy 2013;53:173-8. doi:10.1016/j.energy.2013.02.031.

[69] PureTemp - Global Authority on Phase Change Material n.d. http://www.puretemp.com/ (accessed August 5, 2016).

[70] Rubitherm. Phase change materials n.d. http://www.rubitherm.eu/en//index.html (accessed January 15, 2016).

[71] Climator n.d. http://climator.com/ (accessed August 5, 2016).

[72] Cristopia Energy Systems. India n.d. http://cristopia.co.in/ (accessed August 5, 2016).

[73] Cristopia Energy Systems. France n.d. https://www.cristopia.com/ (accessed August 5, 2016).

[74] PCM Energy n.d. http://www.pcmenergy.com/ (accessed August 5, 2016).

[75] PCM Products Ltd n.d. http://www.pcmproducts.net/ (accessed August 5, 2016).

[76] Phase Change Materials - BASF http://www.micronal.de/portal/basf/ien/dt.jsp?setCursor=1_290798 (accessed April 26, 2016).

[77] RGees Energy Efficiency Systems n.d. http://rgees.com/ (accessed August 5, 2016).

[78] Ramakrishnan S, Wang X, Sanjayan J, Wilson J. Thermal performance of buildings integrated with phase change materials to reduce heat stress risks during extreme heatwave events. Applied Energy 2016. doi:10.1016/j.apenergy.2016.04.084.

[79] Mi X, Liu R, Cui H, Memon SA, Xing F, Lo Y. Energy and economic analysis of building integrated with PCM in different cities of China. Applied Energy 2016;175:324-36. doi:10.1016/j.apenergy.2016.05.032.

[80] Castell A, Martorell I, Medrano M, Pérez G, Cabeza LF. Experimental study of using PCM in brick constructive solutions for passive cooling. Energy and Buildings 2010;42:534-40. doi:10.1016/j.enbuild.2009.10.022.

[81] Cabeza LF, Castellón C, Nogués M, Medrano M, Leppers R, Zubillaga O. Use of microencapsulated PCM in concrete walls for energy savings. Energy and Buildings 2007;39:113-9. doi:10.1016/j.enbuild.2006.03.030.

[82] Castell A, Menoufi K, de Gracia A, Rincón L, Boer D, Cabeza LF. Life Cycle Assessment of alveolar brick construction system incorporating phase change materials (PCMs). Applied Energy 2013;101:600-8. doi:10.1016/j.apenergy.2012.06.066.

[83] de Gracia A, Rincón L, Castell A, Jiménez M, Boer D, Medrano M, et al. Life Cycle Assessment of the inclusion of phase change materials (PCM) in experimental buildings. Energy and Buildings 2010;42:1517-23. doi:10.1016/j.enbuild.2010.03.022.

[84] Kalaiselvam S, Parameshwaran R. Appendix IV. Parametric and Cost Comparison of Thermal Storage Technologies. Thermal energy storage technologies for sustainability: systems design, assessment, and applications. 1st ed., Academic Press; 2014, p. 399-400. 
[85] Cool-phase. Natural Cooling and Low Energy Ventilation. Monodraught Ltd n.d. http://www.cool-phase.net/ (accessed April 11, 2016).

[86] Monodraught. Cool-phase. Low energy cooling and ventilation system. Commercial data 2012. http://www.coolphase.net/pdfs/system-types_2.pdf.

[87] Cui B, Gao D, Xiao F, Wang S. Model-based optimal design of active cool thermal energy storage for maximal life-cycle cost saving from demand management in commercial buildings. Applied Energy 2016. doi:10.1016/j.apenergy.2016.12.035.

[88] Kalaiselvam S, Parameshwaran R. Chapter 6: Thermochemical energy storage. Thermal energy storage technologies for sustainability: systems design, assessment, and applications. 1st ed., Academic Press; 2014, p. 127-44.

[89] Bales C, Gantenbein P, Jaenig D, Kerskes H, Summer K, Van Essen M, et al. Laboratory Tests of Chemical Reactions and Prototype Sorption Storage Units. A Report of IEA Solar Heating and Cooling Programme - Task 32: Advanced Storage Concepts for Solar and Low Energy Buildings 2008.

[90] Bales C, Gantenbein P, Jaehnig D, Kerskes H, van Essen M, Weber R, et al. Chemical and Sorption Storage. EUROSUN 2008 1st International Congress on Heating, Cooling, and Buildings, Lisbon, Portugal: 2008.

[91] International Energy Agency. Solar Heating and Cooling Programme (IEA SHC) - Solar heating, Solar cooling, Solar tasks n.d. http://www.iea-shc.org/ (accessed April 21, 2016).

[92] Weber R, Dorer V. Long-term heat storage with $\mathrm{NaOH}$. Vacuum 2008;82:708-16. doi:10.1016/j.vacuum.2007.10.018.

[93] Quinnell JA, Davidson JH. Mass transfer during sensible charging of a hybrid absorption/sensible storage tank. Energy Procedia 2012;30:353-61. doi:10.1016/j.egypro.2012.11.042.

[94] N'Tsoukpoe KE, Le Pierrès N, Luo L. Experimentation of a LiBr-H2O absorption process for long-term solar thermal storage: Prototype design and first results. Energy 2013;53:179-98. doi:10.1016/j.energy.2013.02.023.

[95] Quinnell J a., Davidson JH, Burch J. Liquid Calcium Chloride Solar Storage: Concept and Analysis. Journal of Solar Energy Engineering 2011;133:11010. doi:10.1115/1.4003292.

[96] Mette $B$, Kerskes $H$, Drück $H$, Müller-Steinhagen $H$. New highly efficient regeneration process for thermochemical energy storage. Applied Energy 2013;109:352-9. doi:10.1016/j.apenergy.2013.01.087.

[97] Vanhoudt D, Claessens B, De Ridder F, Reynders G, Cuypers R, Oversloot H, et al. Energy-Hub for residential and commercial districts and transport. D3.2 Report on a combination of thermal storage techniques and components 2014.

[98] Stitou D, Mazet N, Mauran S. Experimental investigation of a solid/gas thermochemical storage process for solar air-conditioning. Energy 2012;41:261-70. doi:10.1016/j.energy.2011.07.029.

[99] Wagner W, Janhig W, Isaksson D, Hausner R. Modularer energiespeicher nach dem sorptionprinzip mit hoher energiedichte - Modestore, Technology report 2006.

[100] Energy-Hub for residential and commercial districts and transport - E-hub project (2010-2014) - Collaborative European project (7FP) n.d. http://www.e-hub.org/index.html (accessed June 9, 2016).

[101] Finck C, Henquet E, Van Soest C, Oversloot $H$, De Jong AJ, Cuypers R, et al. Experimental results of a $3 \mathrm{kWh}$ thermochemical heat storage module for space heating application. Energy Procedia 2014;48:320-6. doi:10.1016/.egypro.2014.02.037.

[102] Compact thermal storage technologies - COMTES Project (2012-2016) - Collaborative European project (7FP) n.d. http://comtes-storage.eu/comtes-project/ (accessed June 9, 2016).

[103] Helden W Van, Wagner W, Schubert V, Krampe-Zadler C, Kerskes H, Bertsch F, et al. Experimental tests on a solid sorption prototype for seasonal solar thermal storage. Eurotherm Seminar \#99: Advances in Thermal Energy Storage 2014:1-8.

[104] Zettl B, Englmair G, Steinmaurer G. Development of a revolving drum reactor for open-sorption heat storage processes. Applied Thermal Engineering 2014;70:42-9. doi:10.1016/j.applthermaleng.2014.04.069. 
[105] Johannes K, Kuznik F, Hubert J-L, Durier F, Obrecht C. Design and characterisation of a high powered energy dense zeolite thermal energy storage system for buildings. Applied Energy 2015;159:80-6. doi:10.1016/j.apenergy.2015.08.109.

[106] Hauer A. Adsorption Systems for Tes-Design and Demonstration Projects. Thermal Energy Storage for Sustainable Energy Consumption, vol. 13, Netherlands: Springer; 2007, p. 409-27. doi:10.1016/03787788(89)90020-0.

[107] Hui L, Edem NK, Nolwenn LP, Luo L. Evaluation of a seasonal storage system of solar energy for house heating using different absorption couples. Energy Conversion and Management 2011;52:2427-36. doi:10.1016/j.enconman.2010.12.049.

[108] Berg Johansen J, Furbo S. COMTES - Deliverable 5.1 : Description of experimental systems 2015.

[109] Daguenet-Frick X, Gantenbein P, Frank E, Fumey B, Weber R, Williamson T. Seasonal Thermal Energy Storage with Aqueous Sodium Hydroxide. Reaction Zone development, manufacturing and first experimental assessments. EuroSun 2014 ISES Conference Proceedings, Aix-Les-Bain, France: 2014. doi:10.1016/j.egypro.2014.10.251.

[110] Daguenet-Frick X, Gantenbein P, Frank E, Fumey B, Weber R, Williamson T. Reaction zone development for an aqueous sodium hydroxide seasonal thermal energy storage. Energy Procedia 2014;57:2426-35. doi:10.1016/j.egypro.2014.10.251.

[111] Fumey B, Weber R, Gantenbein P, Daguenet-Frick X, Williamson T, Dorer V. Closed sorption heat storage based on aqueous sodium hydroxide. Energy Procedia 2014;48:337-46. doi:10.1016/j.egypro.2014.02.039.

[112] van Essen VM, Zondag HA, Gores JC, Bleijendaal LPJ, Bakker M, Schuitema R, et al. Characterization of MgSO4 Hydrate for Thermochemical Seasonal Heat Storage. Journal of Solar Energy Engineering 2009;131:17. doi:10.1115/1.4000275.

[113] Zondag H, KikkertB, Smeding S, Boer R de, Bakker M. Prototype thermochemical heat storage with open reactor system. Applied Energy 2013;109:360-5. doi:10.1016/j.apenergy.2013.01.082.

[114] Lammak K, Wongsuwan W, Kiatsiriroj T. Investigation of modular chemical energy storage performance. Proceedings of the Joint International Conference on Energy and Environment, Hua Hin, Thailand; 2004.

[115] de Boer R, Haije WG, Veldhuis JBJ, Smeding SF. Solid-sorption cooling with integrated thermal storage: the SWEAT prototype. Proceedings of HPC 2004-3rd International Heat Powered Cycles Conference, Larnaca, Cyprus: 2004.

[116] Mauran S, Lahmidi H, Goetz V. Solar heating and cooling by a thermochemical process. First experiments of a prototype storing $60 \mathrm{kWh}$ by a solid/gas reaction. Solar Energy 2008;82:623-36. doi:10.1016/j.solener.2008.01.002.

[117] Kerskes H, Mette B, Bertsch F, Asenbeck S, Drück H. Chemical energy storage using reversible solid/gasreactions (CWS) - Results of the research project. Energy Procedia 2012;30:294-304. doi:10.1016/j.egypro.2012.11.035.

[118] Cot-Gores J, Castell A, Cabeza LF. Thermochemical energy storage and conversion: A-state-of-the-art review of the experimental research under practical conditions. Renewable and Sustainable Energy Reviews 2012;16:5207-24. doi:10.1016/j.rser.2012.04.007. 